

\title{
A desaceleração chinesa e o "Novo Normal": implicações estruturais para a economia e o setor financeiro doméstico
}

\author{
The Chinese slowdown and the "New \\ Normal": structural implications for the \\ economy and the domestic financial sector
}

* Rafael Shoenmann de Moura

\section{Resumo}

Após décadas de crescimento econômico robusto, facultando crescente proeminência geopolítica no sistema interestatal capitalista, a China dá sinais de desaceleração em meio a profundas mudanças e incertezas em seu regime produtivo. Conforme a estratégia de desenvolvimento prévia, com forte participação dos investimentos e do desempenho exportador, parece esgotar-se, um novo cenário se desenha, com distintas oportunidades e riscos. Assim, mediante dados empíricos e literatura pertinente, este trabalho fará uma reflexão conjuntural sobre o paradigma do "Novo Normal" e seus desdobramentos para a trajetória futura da potência asiática, problematizando possíveis transformações na interlocução entre instituições de Estado e de mercado, principalmente no setor financeiro.

Palavras-chave: China; "Novo Normal”; Instituições; Sistema Financeiro; Desenvolvimento Econômico.

\begin{abstract}
After decades of robust economic growth, providing increased geopolitical prominence in the capitalist interstate system, China shows signs of slowing down amid deep changes and uncertainties in its productive regime. As the previous development strategy, with strong participation of investment and export performance, seems to run out, a new scenario is drawn, with distinctive opportunities and risks. Thus, through empirical data and relevant literature, this work aims a conjectural reflection on the paradigm of the "New Normal" and its impact on the future trajectory of the Asian power, discussing possible changes in the dialogue between State and market institutions, especially in the financial sector.
\end{abstract}

Keywords: China; "New Normal"; Institutions; Financial System; Economic Development.

\footnotetext{
* Doutorando pelo Programa de Pós-Graduação em Ciência Política do Instituto de Estudos Sociais e Políticos (IESP-UERJ). Mestre em Ciência Política pela mesma instituição. Pesquisador vinculado ao Núcleo de Estudos do Empresariado, Instituições e Capitalismo (NEIC) e ao INCT/PPED. Membro do corpo editorial do periódico eletrônico "Revista Ponto de Vista: Perspectivas sobre o Desenvolvimento". Estuda principalmente as temáticas de variedades de capitalismo; economia política chinesa; relações Estado-mercado e globalização. Email: rafaelmoura5028@gmail.com .
} 


\section{Introdução}

$\mathrm{O}$ presente artigo apresenta uma reflexão acerca da variedade chinesa de capitalismo e o papel estrutural nela ocupado pelas finanças, dentro de uma economia política internacional pré e pós-crise. Através de uma interpretação qualitativa de dados empíricos, serão problematizadas as relações entre Estado e mercado, e entre setor público e privado no país asiático, elucidando para onde apontam as reestruturações recentes, em meio a um turbulento cenário tanto no âmbito doméstico quanto sistêmico.

A hipótese geral aqui tratada é que a organização do sistema financeiro chinês, de cunho mais fechado e com maior ingerência estatal vis-à-vis outras nações capitalistas avançadas, foi um pilar importante para a sustentação da economia política pósreformas, na medida em que blindou o gigante asiático das turbulências e choques adversos da globalização e da volatilidade dos mercados externos. Conforme se dava uma crescente integração chinesa no sistema mundial, diversos atores passaram a nutrir expectativas de que o País do Meio pudesse executar mudanças neste sistema em vigor, conferindo maior rol aos investidores privados e ao mercado enquanto lócus de financiamento e alocação de recursos. No entanto, diante das dificuldades imanentes à "segunda" transição de modelo suscitada pela desaceleração econômica, requerendo fundamentos mais voltados para o consumo doméstico e o setor de serviços, é presumível uma maior cautela dos governantes da China quanto à liberalização dos mercados de capitais, na medida em que a estabilidade social interna representa um eixo norteador mais imediato do que quaisquer outros objetivos estratégicos.

O delineamento obedecerá esta ordem: a primeira seção buscará reconstituir breve e historicamente os traços do regime produtivo chinês pós-transição, detendose nos contornos gerais e peculiaridades das reformas de mercado postas em curso por Deng Xiaoping e continuadas por Jiang Zemin, Hu Jintao e Xi Jinping, pontuando as mais importantes nuances dentre as políticas econômicas perseguidas pelos gestores nacionais. A segunda seção, por sua vez, esmiuçará em detalhes o papel alocador exercido pelas principais instituições componentes do sistema financeiro dentro do processo de acumulação de capital, tratando de suas consequências para os arranjos sociais domésticos. Na terceira, será discutido e problematizado o "Novo Normal", arquétipo que se coloca para as autoridades e policymakers chineses, na medida em que o país passa por uma desaceleração econômica, resultado direto tanto de suas próprias contradições internas quanto dos efeitos ocasionados pela crise do subprime estadunidense de 2008. As considerações finais, fechando o trabalho, tangem às modificações almejadas pelos gestores do Partido Comunista Chinês (PCC) dentro de tal paradigma mencionado, com olhar detido na adaptação do mercado financeiro e de capitais ao novo cenário, de modo a não obstaculizar uma redesenhada estratégia de desenvolvimento. 


\section{A Economia Política Chinesa: elementos do regime produtivo pós-reformas}

A partir das reformas institucionais anunciadas pelo líder Deng Xiaoping em 1978, a China adentra em uma nova fase histórica de desenvolvimento, reorientando a economia maoísta planificada para um modelo capitalista de forte intervencionismo do Estado, modificando seu próprio ordenamento produtivo. Com considerável pragmatismo, engendra um processo transicional gradualista rumo a uma maior abertura, condicionando mutuamente a dinâmica doméstica e os fatores internacionais (Amsden et al., 1996; Medeiros, 1999; McNally, 2008). Somado a isto, objetivando um catch-up industrial com relação aos países avançados, o governo adota uma estratégia híbrida de arranjos políticos e sociais, mesclando elementos de estatismo e liberalismo, fora além da absorção de diversas influências globais ${ }^{1}$; tudo com experimentações e flexibilidade. Este conjunto de fatores, no decorrer dos anos, teve êxito em render um considerável avanço tecnológico ${ }^{2}$, situando o caso chinês para além dos meros debates dicotômicos, representando um mix dinâmico e simbiótico entre Estado planejador e um modelo liberal (Amsden et al., 1996: p.276; McNally, 2014: p.78).

A exuberante trajetória de crescimento econômico do país (média de quase 10\% a.a., conforme o gráfico 1) foi puxada, em larga medida, pelos ganhos de produtividade na indústria; muito embora, nos anos iniciais das reformas, a expansão do setor primário tenha tido maior destaque (Amsden et al., 1996: p.274). Isto guarda relação direta com as profundas mudanças estruturais operando na composição do emprego e na veloz urbanização do campo naquele momento, concomitante ao expansionismo rural nãoagrícola pautado nas Empresas dos Municípios e Vilas (EMV). É somente a partir de 1983 que passa a haver efetivamente protagonismo da indústria leve voltada para bens de consumo, em meio a alterações no padrão aquisitivo populacional ${ }^{3}$. Também deve ser destacado, tendo por referência exclusiva a década de 1980, a elevação do montante de investimentos brutos para formação de capital (em torno de $30 \%$ do PIB em média, conforme o gráfico 2), liderados majoritariamente pelas empresas estatais que compunham mais de $65 \%$ do valor total, seguidas das EMV (de caráter organizacional coletivo) e do setor privado. Essas estatais, em sua maioria, atuavam para expandir a capacidade produtiva industrial, particularmente na oferta de energia. As exportações também começavam a demonstrar dinamismo: tratava-se do começo de uma resposta à própria escala de abertura chinesa, à sua taxa de câmbio favorável e aos arranjos institucionais mais liberais e flexíveis das áreas de processamento instaladas nas Zonas Econômicas Especiais - ZEE (Medeiros, 1999: p.96-7).

Já no início da década de 1990, tornava-se cada vez mais imperativo para o Partido-Estado renovar o processo reformista, visando construir o alardeado ideal de "socialismo de mercado". Esse ímpeto se justificava pelas turbulências dos anos pregressos, incluindo o episódio das manifestações estudantis de Tiananmen (1989), que havia deteriorado a imagem do país na comunidade internacional; e os receios 
de erosão da ordem política ocasionados pelo fim da União Soviética. Por isso, a própria celebração do septuagésimo aniversário do PCC (1991) foi marcada por uma postura extremamente defensiva dos líderes partidários (Saich, 2015: p.54). Estava em jogo o estabelecimento de uma agenda futura no XIV Congresso do Partido ${ }^{4}$, que definiria o legado político e social de um combalido Deng ${ }^{5}$. Esta agenda acabaria por ser determinada e colocada em prática a partir da própria "turnê" que o líder fez ao sul do país, onde apregoou a aceleração de reformas institucionais de fortalecimento econômico e integração. Após tais desdobramentos, houve um revigoramento modernizante através do ingresso maciço de investimentos (questão tratada ainda nesta

\section{Gráfico 1 - Crescimento do PIB chinês e Participação das Exportações e Importações como porcentagem (\%), 1981-2015}

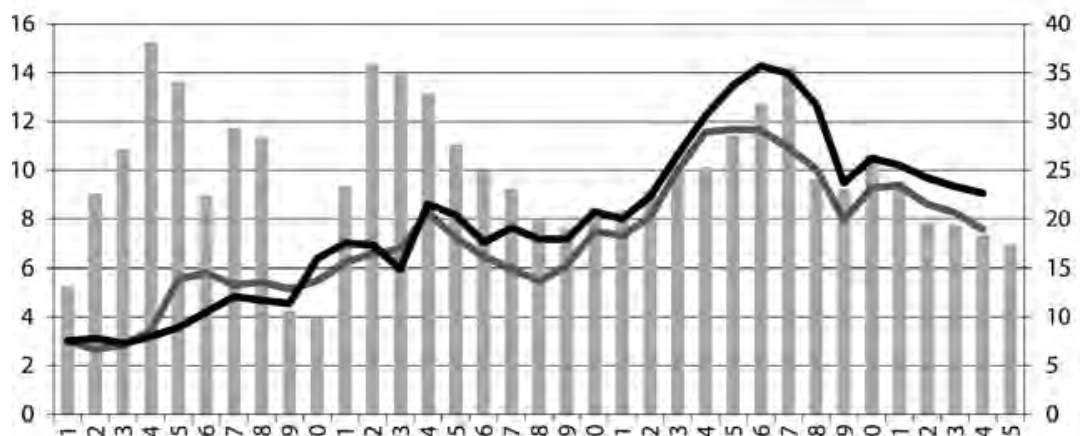

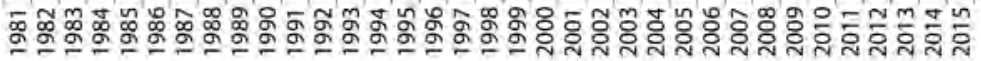

$=$ Crescimento do PIB (\% a.a.) $\quad$ \% IMP/PIB $-\%$ EXP/PIB

Fonte: Elaboração própria a partir de World Bank, World Development Indicators.

Gráfico 2 - Trajetória da Formação Bruta de Capital Fixo (FBCF) na China (\% do PIB), 1981-2014.

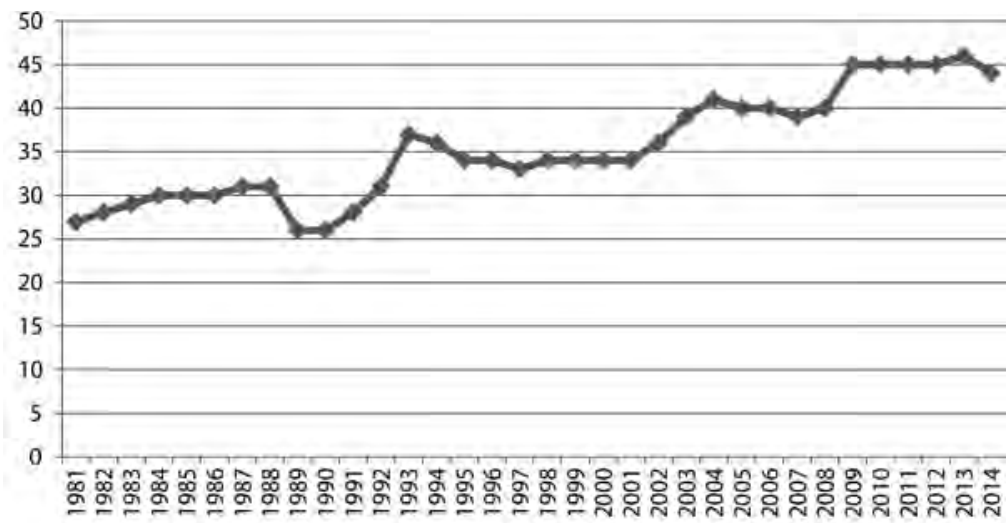

Fonte: Elaboração própria a partir de World Bank, World Development Indicators. 
seção) e valorização imobiliária, tornando a China um grande pólo de obras e projetos de distintas naturezas.

O declínio relativo das EMV, também deste período, levou os governantes chineses, principalmente em esferas locais, a abraçarem cada vez mais o processo formal de privatizações, convergindo estruturas de governança particular e estatal. Dentro da orientação de enxugamento do setor público, contudo, foi mantido o controle do Estado sobre as maiores empresas e as pertencentes a setores estratégicos ${ }^{6}$, apesar de terem sido feitas mudanças em suas estruturas corporativas ${ }^{7}$. Paralelamente, essas reformas administrativas também consolidaram a burocracia governamental, com a política industrial passando a ser determinada de forma supraministerial. Todas essas alterações conduzem à reflexão de como o processo reformista chinês não representou, absolutamente, um recuo unilateral do Estado em função das forças privadas de mercado (McNally, 2014: p.64-5). Ademais, dentro de sua imersão no capitalismo global, destaca-se a liberalização paulatina da estrutura de preços ${ }^{8} \mathrm{e}$ o aumento da autonomia das estatais (State-Owned Enterprises - SOE) como pontos mantenedores da estabilidade política e social. Na primeira metade dos anos 1990, a contínua expansão da indústria já havia atingido um extremo excesso de capacidade e competição, incorrendo em problemáticas fiscais que só seriam equacionadas com essas privatizações, de caráter pleno ou parcial. A partir daí, com maior densidade de um setor privado pulsante, houve empenho por parte do Estado em aprimorar o ambiente regulatório e abrir ainda mais o país para comércio e investimentos, acelerando o curso já em voga (McNally, 2008: p.25-6).

Holisticamente falando, dois fatores também se provaram indeléveis para o sucesso chinês: a lógica dos investimentos, voltada para nichos intensivos em capital; e o desempenho das exportações, intensificadas principalmente na década de 2000 com o ingresso na Organização Mundial do Comércio (OMC). Ambos se amalgamavam, com a capacidade exportadora surfando na ampliação do investimento externo direto (IED), ao passo que inversões públicas em segmentos atados à iniciativa estrangeira criavam potencialidades produtivas e comerciais (Medeiros, 2010; Vermeiren e Dierckx, 2012). Para uma interpretação export-led, o principal desafio do padrão desenvolvimentista da China seria mitigar a dependência externa mediante incremento da demanda doméstica. A redução do saldo comercial superavitário com os EUA, normalmente traduzido no acúmulo de reservas externas ou na compra de títulos da própria dívida estadunidense, também contribuiria para uma possível redução de imbróglios comerciais e pressões. Ao mesmo tempo, em uma segunda interpretação, o fundamento do crescimento sustentado estaria na inevitável mudança na composição da demanda, incorporando maior consumo das famílias e focando em indústrias intensivas em mão de obra, com uma distribuição de renda mais equânime. Os próximos parágrafos analisarão melhor essas duas esferas em questão (investimentos e comércio exterior). 
A liberalização dos fluxos de IED, um dos componentes mais tangíveis das mudanças estruturais, foi bastante tênue na fase incipiente das reformas, se intensificando apenas na década de 1990 (ver gráfico 3), com a reiteração da política das ZEE $^{9}$ e sua alta concentração espacial. Em meio às divergências internas no seio do Partido-Estado entre uma ala mais conservadora e outra liberal, Deng tecia um discurso mobilizador capaz de convencer ambas quanto aos louros da síntese que almejava, aproveitando vantagens tanto do planejamento estatal quanto da flexibilização para acesso ao capital estrangeiro (Saich, 2015: p.56). Nas ZEE, as inversões se dirigiam com exclusividade para setores de mercado voltados ao exterior, principalmente a partir da província de Guangdong, em função da proximidade e articulação com as cadeias regionais (Hong Kong, Japão, Taiwan, etc.). O principal modelo estruturante de tais relações era o de joint ventures, constituindo capacidades produtivas imbuídas do posterior atendimento do mercado interno, sem contar na relevante transferência tecnológica que acresciam para o domínio nacional (Medeiros, 1999: p.97). Além disso, contribuiu para tal padrão de investimentos uma gama de condições geopolíticas específicas, dentre elas o deslocamento de empresas guiadas pela lógica de outsourcing a partir da década de 1980, desejosas por aproveitar as vantagens comparativas baseadas na força laboral disciplinada e nos baixos custos produtivos chineses.

Gráfico 3 - Participação dos Investimentos Externos Diretos (IED) no PIB (\%), 1982-2014.

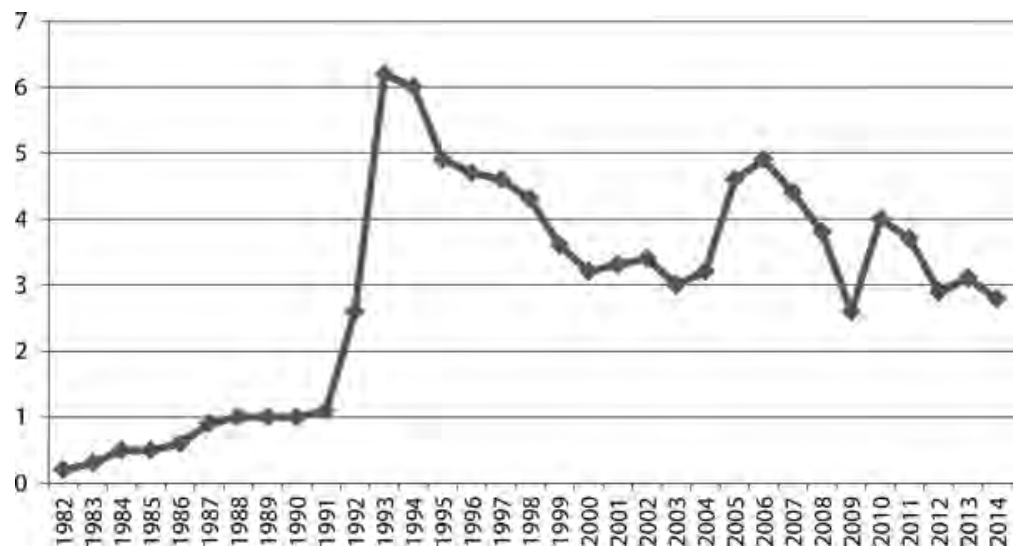

Fonte: Elaboração própria a partir de World Bank, World Development Indicators.

Quanto ao comércio exterior, não obstante o desmantelamento da economia planificada, o Estado permaneceu instrumentalizando uma série de medidas de gerenciamento, desde tarifas convencionais e políticas de cotas a controles tácitos, como licenças estatais de direitos de troca e inspeções de commodities ${ }^{10}$. Até metade dos 
anos 1980, por exemplo, a China aplicava altíssimos tributos sobre bens importados. Enquanto que a modesta redução das tarifas na primeira década de reformas foi parcialmente ofuscada por um grande aumento no uso de cotas, as elevadas desonerações tarifárias dos anos 1990 representaram um desmonte quase unilateral, almejando a futura entrada na OMC (concretizada em 2001) ${ }^{11}$. O ritmo gradual de liberalização pode ser visto pelo próprio número de firmas nacionais autorizadas a se engajarem nas relações externas: de 12 em 1979 para 12.000 em 1995 e 35.000 em 2001 (Edmonds et al., 2008: p.171). Denota-se aqui uma curiosa dualidade do próprio sino-capitalismo na incorporação das forças globalizantes: um certo grau de "descolamento", em algum sentido, desses grandes polos industriais da economia doméstica, inclinando-se preponderantemente para a integração competitiva nas fragmentadas cadeias produtivas mundiais (McNally, 2014: p.67-8).

Uma ressalva aqui imprescindível se relaciona à polêmica sobre a caracterização da economia política chinesa enquanto pautada eminentemente pelas exportações ("export-led") 12. Não desprezando sua importância estratégica, o setor exportador do país responde apenas por uma parcela moderada da economia como um todo, em uma cifra inferior vis-à-vis outras economias asiáticas; de modo que os receios sobre dissociação do ciclo global ou da demanda mundial agregada seriam injustificados (Anderson, 2007: p.1-2). Ademais, como atesta o gráfico 4, o mapeamento da correlação entre as taxas de crescimento econômico e do comércio em um recorte histórico pós-reformas permite corroborar como o desempenho produtivo encontra notável grau de estabilidade, a despeito das oscilações comerciais externas, sejam elas mais tênues ou agudas (Anderson, 2007: p.8).

Dos anos 1980 até o presente, a composição da pauta comercial chinesa também se transformou rápida e qualitativamente. De uma economia especializada em pro-

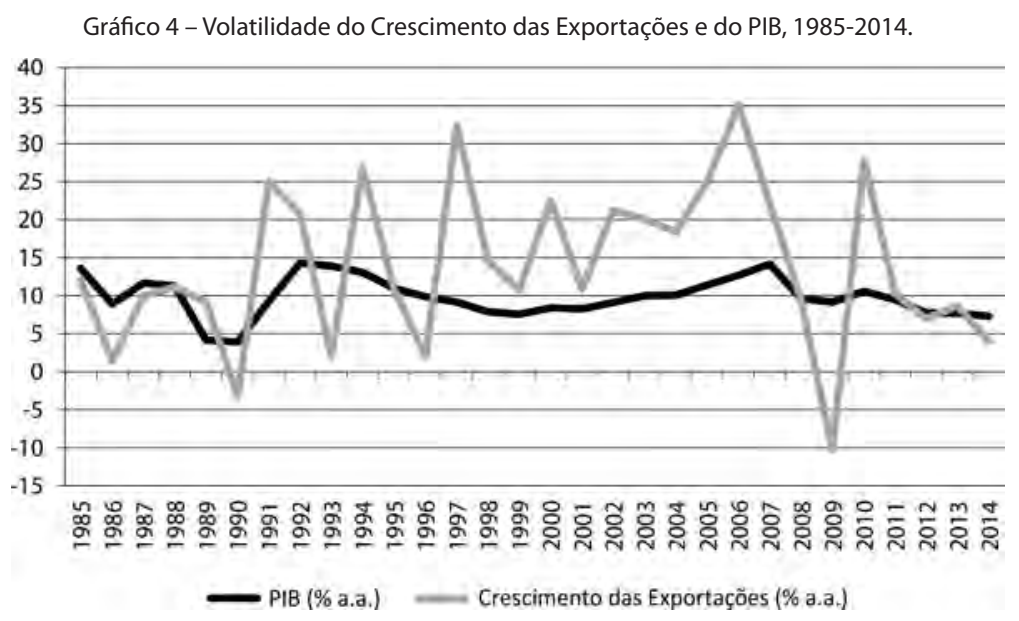

Fonte: Elaboração própria a partir de World Bank. World Development Indicators. 
dutos de baixa qualidade, intensivos em trabalho e com tecnologias relativamente simples para a produção de bens intensivos em capital, mais elaborados e técnicos, como eletrônicos e afins (ver gráfico 5). Tal evolução não é propriamente uma peculiaridade chinesa, sendo elemento comum também no padrão das experiências desenvolvimentistas do Leste Asiático que se mostraram capazes de "subir a escada de qualidade" durante seus ciclos de alto crescimento. Já os rápidos incrementos na importação de bens intermediários, conforme pontuado por Edmonds et al., fornecem outro sinal de que setores de altas tecnologias e de trabalhos mais refinados continuam a evoluir drasticamente (2008: p.180).

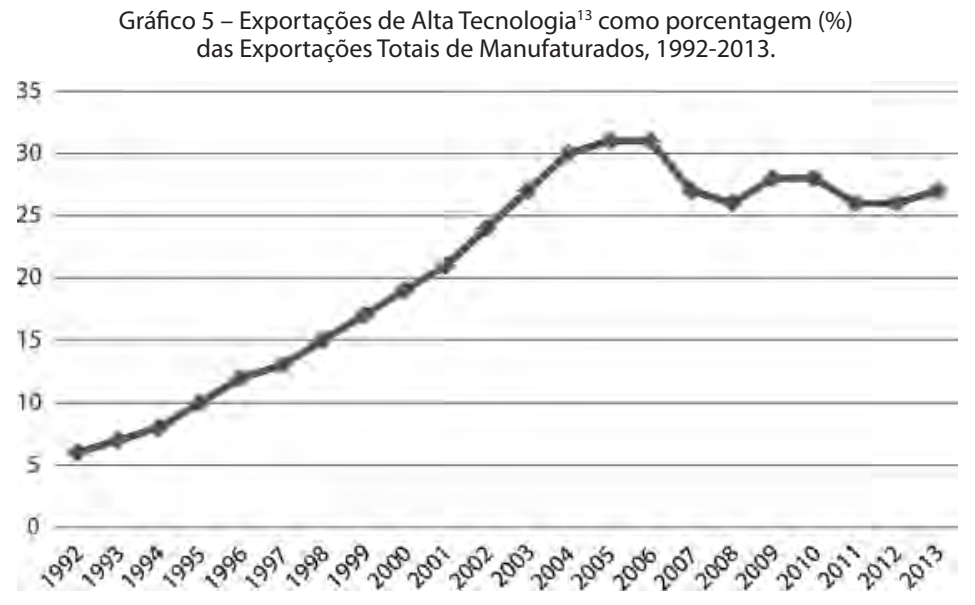

Fonte: Elaboração própria a partir de World Bank. World Development Indicators.

Mais recentemente, nos anos 2000, sob o mandato de Hu Jintao e Wen Jiabao (que assumem o governo em 2002), auxiliados pela aceleração econômica, houve forte impulso dos investimentos em infraestrutura, particularmente em estradas e construções de conjuntos habitacionais. Estes pontos reverberaram uma tendência inexorável de acentuação do processo urbanizador, já marcante no país havia um tempo (Saich, 2015). Na esteira deste processo, intensificou-se também a injeção de capitais na indústria pesada (setores como aço, ferro, alumínio, vidro e química), ampliando a industrialização substitutiva de importações e a dinâmica de diversificação exportadora, impactando no padrão de crescimento (Medeiros, 2010: p.10-11). Assinalava-se tal expansão desde 1997, embora tivesse sido ampliada nos últimos anos, com a enorme escala do mercado se tornando fonte de atração de investimentos externos e potencialidades de consumo (2010: p.11). Isto também se coadunou com uma relativa descontinuidade, conforme Saich, na orientação política, com o princípio de uma "sociedade harmoniosa" compelindo maior atenção para questões de justiça e bem-estar: foi assim que, por boa parte de sua gestão, Hu buscou 
conciliar o apelo pró-crescimento a qualquer custo com certa moderação para atender a pleitos sociais (2015: p.59).

Somente com a crise financeira e sistêmica de 2008 que será introduzido um fator externo de instabilidade, somando-se aos imensos desafios do gigante asiático. Vendo todas essas pontuações da economia política do país, tal como foi cimentada por um período de três décadas, caberá à próxima seção embrenhar-se no detalhamento de suas instituições financeiras e, em seguida, para a problematização de tais lógicas no atual momento de desaceleração.

\section{O Sistema Financeiro: peculiaridades do desenvolvimento institucional}

Aqui serão analisadas algumas das especificidades regulatórias e estruturais dos principais órgãos financeiros da China, pontuando diferenças com relação a outros países. Primeiramente, uma breve reflexão geral será tecida sobre a amálgama entre Estado e mercado dentro da lógica de financiamento do curso produtivo. Depois, será descrita a arquitetura institucional do Estado chinês no âmbito financeiro. Por fim, serão apontadas contradições em tais arranjos, bem como desafios para o futuro, na medida em que tal exemplo nacional constitui caso único para investigar os mecanismos íntimos de coordenação entre o poder público e a esfera das finanças. Como destaca Wang, este delineamento é importante pelo fato de, ao desdobrar os efeitos de alavancagem mútuos entre ambas as esferas, ilustrar como operaria a endogeneidade de tal modelo quanto à ascensão da dimensão financeira em contexto de forte ingerência estatal, revelando muito também sobre o domínio do poder político (2014: p.603).

Pensando a financeirização da economia enquanto fenômeno global, é curiosa a percepção de como, no caso da potência asiática, a forte presença de atores estatais coloca desafios substantivos à retórica liberalizante comumente alardeada, no sentido de que, em tais processos, os Estados geralmente tenham atuado pelo vetor das desregulamentações ${ }^{14}$. Tal caminho, embora corroborado pelos exemplos de países liberalizados ou avançados, encontra muitas dificuldades quando esquadrinhado dentro de instâncias históricas e contextos nacionais onde os Estados desempenharam papel de atores financeiros de peso, principalmente mediante canalização de recursos para o desenvolvimento e projetos de industrialização. Por essa via, o caso do governo chinês representaria um exemplo primoroso de grande detentor de ativos e investimentos no mercado financeiro.

É importante destacar também como a lógica política sempre permearia cada fase e a consideração dos atores e policymakers do Estado, sendo catalítica sobre a trajetória de expansãofinanceira(Naughton,2007:p.473).Afinanceirização,emsín-tese,representaria mais uma escolha acrescida à convencional gama de ferramentas governamentais disponíveis, também gozando de funções como regulação e orçamentação. 
Dentro do arcabouço explanatório comumente utilizado, os Estados foram quase sempre ofertantes de flexibilizações e medidas facilitadoras de tal processo; de forma que as regulamentações estatais, peças centrais dentro da política macroeconômica (tal como o câmbio e os juros), atuaram como alavancas de indução do comportamento das firmas apenas à distância. Olhando os sinais usuais causados por tal mudança, muitos deles também podem ser atestados na China - com a vasta maioria das empresas sendo corporativizadas e os valores das ações começando a adquirir tração na comunidade de negócios. Entretanto, ainda é preciso atentar para as especificidades dos mercados financeiros chineses, explicitando o real propósito das políticas e instrumentos nele empregados, assim como suas raízes nas hierarquias do Estado e seu elo com uma estratégia de desenvolvimento (Wang, 2014: p.606). As próximas páginas irão se ocupar com tais digressões, não antes de delinear as principais instituições que permitem construir essa narrativa.

Muito do conhecimento existente sobre processos de financeirização adviria de experiências históricas de economias mais liberais; embora valha à pena atentar que, mesmo nestas, os Estados também podem participar ativamente dos mercados financeiros via propriedade estatal, controle governamental dos ativos ou por diferentes esquematizações institucionais de garantia de crédito. Seriam esses fatores que possibilitariam intervenções em momentos de crise econômica. Ainda assim, o exemplo chinês se sobressai pela enorme magnitude do setor estatal e a pesada intervenção pública na esfera econômica, em toda uma variedade de frentes (Wang, 2014: p.607).

Dentro do processo reformista, tomado desde seu início, o setor financeiro apresentou um ritmo de mudanças institucionais bem mais vagaroso vis-à-vis outras áreas e atividades produtivas, sendo praticamente hegemonizado por bancos públicos dotados de alto grau de proteção e regulação, de modo a contar com pesada blindagem da competição internacional (Naughton, 2007: p.449; Medeiros, 2010: p.11; Yang e Huizenga, 2010: p.122). É válido lembrar que a problemática nunca foi propriamente a ausência de inovações organizacionais - muito pelo contrário, o governo efetuou reestruturações bancárias fundamentais e experimentou inúmeros arranjos no mesmo, em todas as distintas gerações de presidentes. Em termos "técnicos", o segmento financeiro da China poderia ser classificado como "profundo" e "estreito"15; com seu mercado de capitais (incluindo o mercado de ações) se encontrando em meio a um árduo período de mudanças, regulamentações e retração, gerando receios entre diferentes atores políticos e econômicos de que o sistema possa se tornar uma potencial fonte de vulnerabilidades.

Algumas grandes tarefas urgem desde a fase mais incipiente do sistema financeiro chinês, sendo uma delas o impedimento de quaisquer turbulências enquanto o país percorre o complexo processo de desenvolvimento e abertura. Para equacionar tal objetivo, torna-se cada vez mais imprescindível a estabilidade do setor bancário; que, comparativamente, é auferido pela participação de $M 2^{16}$ enquanto porcentagem 
do PIB ("profundidade monetária"), crescente ao longo de toda a década de 1990 e chegando ao patamar de quase $200 \%$ do produto interno bruto em 2014, maior do que qualquer outro país em desenvolvimento ou desenvolvido, excetuando o Japão (ver gráficos 6 e 7). É justamente o tremendo dimensionamento do setor bancário, responsável por quase $80 \%$ de toda intermediação creditícia ${ }^{17}$, que contribui, dentre

Gráfico 6 - "Aprofundamento financeiro": M2 e Depósitos em Poupança Familiar como porcentagem (\%) do PIB, 2006-2014.

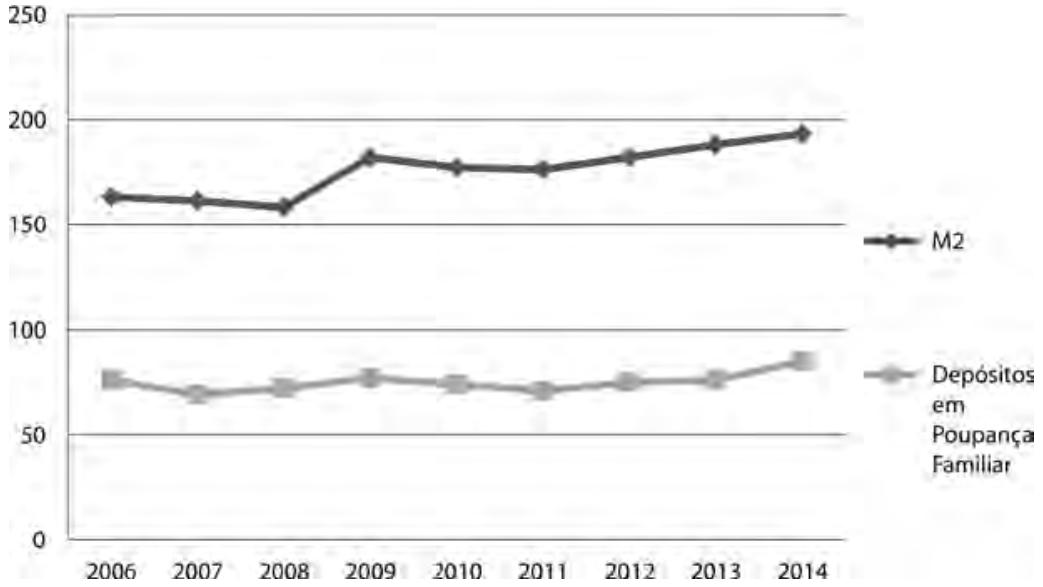

Fonte: The People's Bank of China. Annual Report, Vários anos; National Bureau of Statistics. China Statistical Yearbook 2015. Compilado a partir da seção 19-14 (NBS).

Gráfico 7 - Profundidade monetária chinesa em perspectiva comparada (\% do PIB), 2014.

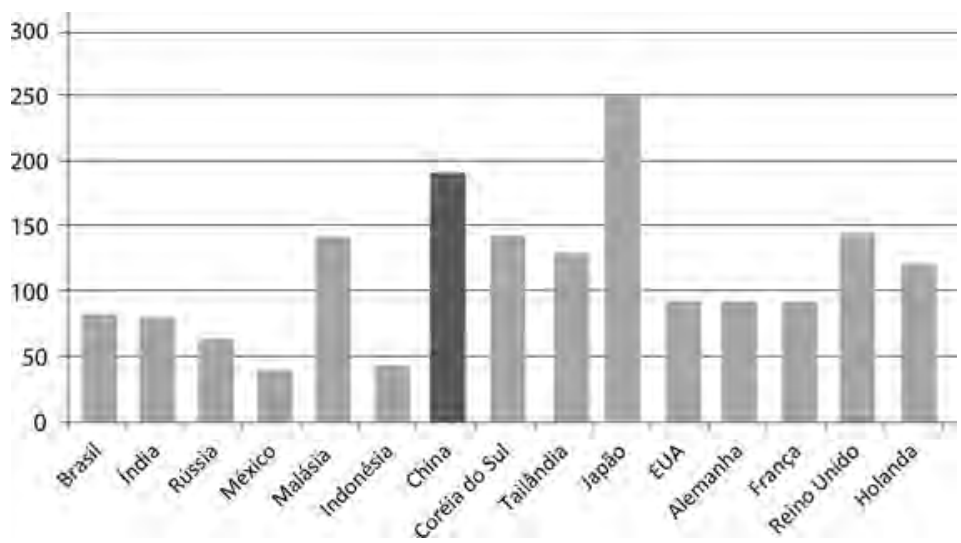

Fonte: Elaboração própria a partir de World Bank. World Development Indicators; Trading Economics. Trading Economics Database. Disponível em <http://www.tradingeconomics.com/>. 
diversos fatores, para os receios acerca do equilíbrio fiscal e monetário do País do Meio (Naughton, 2007: p.479; Vermeiren e Dierckx, 2012: p.1656). Mesmo com a notável capitalização do sistema bancário e a eliminação de trilhões de renminbi (RMB) em empréstimos improdutivos, o potencial de perdas se manteria significativo. Simplesmente pela própria escala de tal estrutura, o volume de empréstimos e o risco de calote relacionado ao PIB é gigantesco. Portanto, preocupações são compreensíveis e persistentes tanto com bancos comerciais quanto com instituições financeiras.

Em segundo lugar, há também a necessidade de criar um virtuoso círculo alocador de recursos com a ajuda de um sistema financeiro eficiente, gozando de uma supervisão bem executada e maior accountability na estrutura de governança corporativa. Transmissores financeiros intermediários, como fundos de pensão e/ou fundos mútuos, neste sentido, serviriam para o fornecimento de seguridade social a segmentos grandes da população. Tais pontos merecem especial enfoque, ainda mais em vista da estrutura demográfica nacional, com um envelhecimento a passos largos colocando pressões futuras sobre a previdência. Para além desse fator, a própria entrada na OMC em 2001 colocou pontos adicionais para a remoção dramática das restrições sobre atividades de bancos externos, gerando prognósticos de competição mais agressiva em tal setor no decorrer dos anos. Assim, se a China for capaz de manter a estabilidade financeira pela próxima década, será cada vez mais plausível antecipar um ritmo extraordinariamente veloz de desenvolvimento, conforme os ativos se ampliem e diversifiquem, começando a cumprir as necessidades de uma economia dinâmica (Naughton, 2007: p.481).

A despeito destes potenciais benefícios provenientes da abertura e diversificação de mercados, a abordagem cautelosa da China com relação às reformas também guardou importância por ter evitado colapsos financeiros, com as poupanças componentes do sistema bancário sendo resguardadas. Durante os períodos de maior recrudescimento de preços, o Estado foi capaz de conferir-lhes forte protecionismo, mediante medidas institucionais como, por exemplo, juros suplementares ao nível do incremento inflacionário (Naughton, 2007: p.452). Mas tal caminho teve seus custos - munidos do fluxo de caixa no sistema bancário, muitos oficiais do governo se utilizaram dos excedentes para financiamentos e projetos ${ }^{18}$. De forma ampla, no período convencionado como "reforma sem perdedores", compreendendo toda a década de 1980 e parte da de 1990, houve forte dependência da oferta de crédito dos bancos para firmas não-viáveis (insolventes), engendrando um acúmulo de empréstimos improdutivos no setor bancário de propriedade pública (Naughton, 1995; 2007). Tal setor foi, portanto, importantíssimo para blindar os trabalhadores das consequências perniciosas ocasionadas pela crescente competitividade de uma economia recheada de novos entrantes, em virtude do florescimento do setor privado. O sistema político instrumentalizou os recursos do sistema bancário para compensar grupos que, outrossim, seriam "perdedores", mantendo, de tal maneira, a estabilidade 
política e social no processo de transição econômica, muito embora tal lógica não pudesse ser sustentada indefinidamente.

Apenasnofinal dosanos 1990 é quetal questão passou a constituir verdadeiramente uma preocupação para os policymakers. Para a percepção de tal problemática, contribuiu bastante a avaliação dos riscos da crise asiática de 1997 (impondo custos severos a Coréia do Sul, Tailândia, Indonésia, etc.), seguida da deflagração de uma nova postura governamental para assegurar a estabilidade macroeconômica via fortalecimento do segmento financeiro ${ }^{19}$. Ao permitir que outras instituições também detivessem funções nesse sistema, o governo foi cuidadoso em manter o controle sobre o mesmo, tentando controlar robustos fluxos da poupança nacional para o sistema bancário. Tal orientação, sem dúvida, contribuiu para a característica mais notável do sistema financeiro chinês, já denotada aqui: a permanência do predomínio bancário, com os mercados de capitais continuando relativamente subdesenvolvidos (Naughton, 2007: p.453-4). Os mercados de ações do país somente decolariam no início dos anos 1990, embora tenham permanecido ainda com graves deficiências pertinentes à transparência e administração. Sem dúvida, outras economias do Leste Asiático também possuem grandes sistemas bancários, mas, em função dos bancos chineses (ou pelo menos os mais relevantes) serem estatais, sua estrutura financeira acaba sendo também controlada pelo Estado.

Para além dessa questão, atenta-se para outras problemáticas estruturais, como a participação relativamente baixa de ações circulantes/negociáveis (muito embora mudanças estejam acontecendo em tal sentido, como mostra o gráfico 8). Tal rigidez foi produto deliberado de um governo sem a menor urgência em liberalizar os fluxos de capitais. Isto sem contar que, mesmo dentre as ações circulantes disponíveis ao público, havia uma forte segmentação, com diferentes perfis acionários ${ }^{20}$. Em um mercado estruturado dessa forma, o preço das ações acaba se tornando bastante variável conforme cada classificação, com "ineficiências" relativas a padrões de divulgação, regras, volume comercializado, prêmios de risco, liquidez e precificação (Naughton, 2007: p.471-2). Os limites do mercado acionário, naturalmente, provocam diversos efeitos também sobre a atuação dos investidores institucionais, grandes acionistas interessados em monitorar o desempenho de diversas empresas e atuar a fim de aperfeiçoarem a performance e a governança corporativa das firmas no longo prazo. Se é verdade que, desde 2001, tem crescido de forma estável a quantidade de investidores institucionais, isto teria sido tão somente uma resposta à criação de mecanismos como os já falados fundos mútuos; permissão para investidores estrangeiros qualificados atuarem; início da participação de corretoras e cias de seguro; etc. E, ademais, tal alavancagem teria partido de uma base muitíssimo baixa. Em todos esses casos, todavia, a forma legal para novos investidores foi criada e institucionalizada, iniciando maiores fluxos de investimentos, muito embora os montantes, conforme Naughton, ainda sejam baixos quando relacionados ao mercado como um todo (2007: p.476). 
Gráfico 8 - Capitalização dos Mercados de Valores Mobiliários (Cias Domésticas Listadas) como porcentagem (\%) do PIB, 2003-2014.

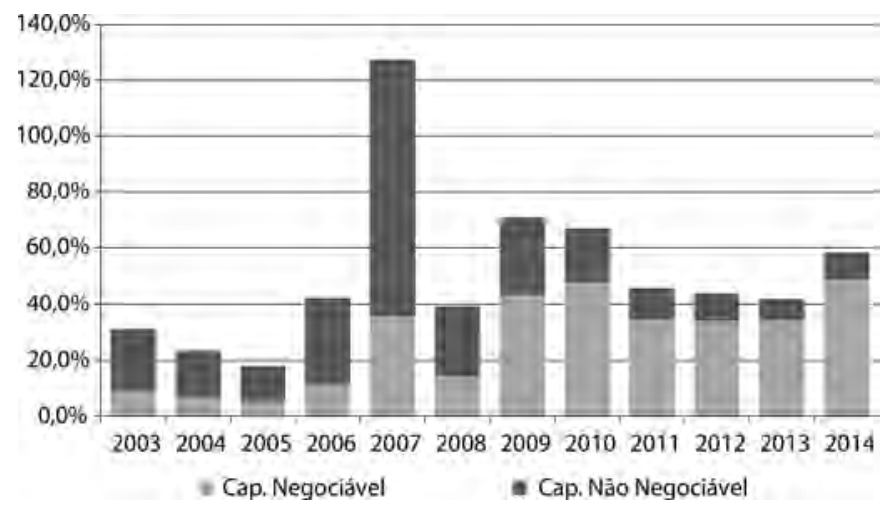

Fonte: National Bureau of Statistics. China Statistical Yearbook. Vários anos. Compilado a partir da seção 19-15.

Gráfico 9 - Ativos das Firmas Estatais (SOE) e Holdings como porcentagem (\%) do PIB, 1998-2013

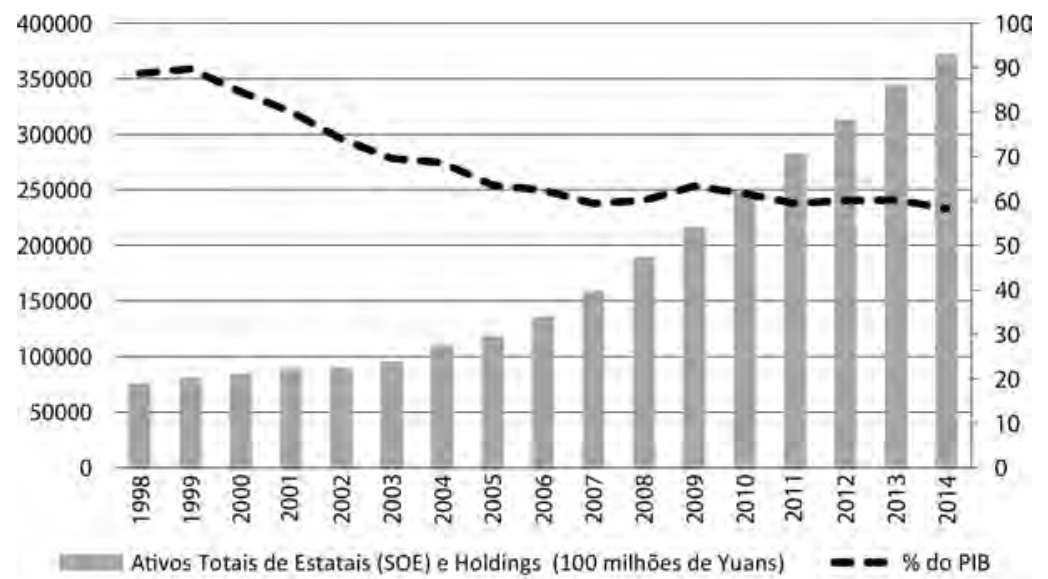

Fonte: Elaboração própria a partir de Gao, 2010; e National Bureau of Statistics. China Statistical Yearbook 2015. Compilado a partir das Seções 3-1 (Categoria: PIB) e 13-4 (Categoria: Mensuração dos ativos totais).

Dentro de uma perspectiva sistêmica, cumpre notar como o modus operandi do mercado financeiro chinês guardaria importantes implicações estratégicas dentro da ordem econômica neoliberal de onde o país emerge, com um regime de controle de capitais representando latente contradição entre suas ambições geopolíticas globais e as forças sociais domésticas de produção (Vermeiren e Dierckx, 2012: p.1647). Se, por um lado, tal regime foi impreterível para consolidar o modelo de acumulação ${ }^{21}$, por outro se veria constrangido pelas próprias possibilidades suscitadas em caso de 
sua flexibilização, tendo em vista que a abertura financeira poderia representar um possível vetor de ampliação do papel internacional da moeda chinesa. Isto seria um paradoxo quase imanente a tal abordagem regulatória para com os fluxos de capitais transfronteiriços, prevenindo o modelo econômico da China de se contrapor a uma das principais normas e inclinações do neoliberalismo global: a livre mobilidade de capitais (Rodrik, 2011: p.106-8; Vermeiren e Dierckx, 2012: p.1648; El-Erian, 2016).

As dinâmicas e consequências de tal política pertinente aos fluxos de capitais somente podem ser entendidas mediante relativo afastamento de dicotomias reducionistas ${ }^{22}$, conferindo destaque às relações sociais de produção na potência asiática, e não apenas a meras narrativas sobre a trajetória liberalizante. Isto jogaria luz sobre mais aspectos do regime produtivo, como a canalização de recursos da população (trabalhadores) para as corporações: não somente para firmas externas orientadas à atividade exportadora, mas também para SOE orientadas domesticamente ${ }^{23}$ (Vermeiren e Dierckx, 2012: p.1651). O esgarçamento analítico dos comedimentos financeiros acaba por relevar também outras duas contradições menores: tal arcabouço regulatório é legitimado por uma ordem política doméstica que incorpora as frações dominantes do capital produtivo e financeiro, sendo pilar institucional sine qua non dentro de uma lógica de acumulação redistributiva de renda para essas mesmas frações. E, em segundo lugar, o próprio anseio geopolítico dos policymakers em projetar o país com maior densidade e influência no sistema monetário e financeiro global se ancora, em muito, na premissa de liberalização, o que significa corroborar a ordem de economia política internacional vigente de mobilidade de fluxos, e não propor um modelo alternativo de governança mundial.

Conforme salientado ao longo da seção, as estatais chinesas, compondo os investimentos em ativos fixos domésticos (embora atualmente em uma proporção um pouco menor com relação ao PIB, vide o gráfico 9), foram e continuam sendo fundamentais para a acumulação de capital na economia política do país. Tal importância, somada à dinâmica mutuamente reforçante entre investimentos e lucros corporativos, transcenderia os simples interesses de corporações transnacionais orientadas para os mercados mundiais ${ }^{24}$. Ademais, o grau de dependência da China com relação às exportações seria, em muito, causado pela própria disparidade entre investimentos corporativos domésticos e o consumo privado, refletindo a previamente assinalada "transferência" de renda dos trabalhadores para as empresas. Um notável indicativo e produto de tal elemento regressivo seria a repressão de salários, cujas cifras (tanto real quanto nominal) teriam subido em patamares inferiores à produtividade do trabalho no setor manufatureiro (Vermeiren e Dierckx, 2012). O resultado disso seria exatamente a redução da participação dos salários no PIB nacional.

Em síntese: a repressão financeira do sistema bancário chinês operou e opera ainda como mecanismo redistributivo primordial dentro da lógica de lucratividade dos investimentos - o Estado fixa os juros sobre depósitos no sistema bancário de modo a facultar aos bancos estatais financiarem os investimentos das SOE a taxas 
de juros baixas. A ausência de um sistema consolidado de seguridade social, por sua vez, deprimiria o consumo e forçaria os trabalhadores a pouparem, ajudando em tal intento. Concomitantemente, as SOE também se beneficiaram significativamente dos empréstimos subsidiados, podendo ampliar suas lucratividades. Vale atentar ainda que tal repressão financeira opera com canalização de fluxos das empresas pequenas e médias, que possuem muito menos acesso ao crédito e são oneradas com maiores juros, para as firmas maiores. (Vermeiren e Dierckx, 2012: p.1656). A manutenção do controle do sistema bancário através do controle das taxas de juros e as restrições da competição para com instituições financeiras externas cristaliza esse modelo de desenvolvimento centrado nas indústrias intensivas em capital subsidiado, ao passo que ajuda a conter a inflação através da restrição de crédito ao mercado consumidor.

O fato de o Estado chinês ter vitoriosamente logrado sua "política de portas abertas" (para o IED), concomitantemente a rigorosos controles de capitais, se contrapõe plenamente à noção de uma China dependente e absorvida pelos processos de reestruturação do capital transnacional. Ao contrapor-se claramente a tais interesses, tal regime acaba se revelando, indubitavelmente, uma resiliente "anomalia" para visões que apontam o país asiático como dotado de uma trajetória incongruente de liberalização. Isso se justifica pelo fato de rigorosas barreiras e regulações institucionais terem efetivamente prevenido a penetração de um grande contingente de corporações internacionais e/ou investidores institucionais estrangeiros no sistema financeiro chinês. Apenas um limitado número era facultado investir, e ainda assim somente limitadas parcelas de fundos em uma gama específica de ativos financeiros domésticos (Naughton, 2007; Vermeiren e Dierckx, 2012).

Por fim, os autores destacam a importante observação de como a tecnocracia do PBOC (People's Bank of China) constituiu um corpo crítico de tal estruturação financeira, apregoando liberalizar as taxas de juros e, consequentemente, a conta de capitais. Este desejo se enquadraria em uma maior adequação do sistema bancário chinês aos moldes do Ocidente e também decorreria de um descontentamento com as constantes intervenções do Conselho de Estado e outros ministérios na política monetária, revelando uma disputa inter-coalizões no seio estatal. O PBOC, desta forma, seria tradicionalmente um dos mais relevantes órgãos a advogar um grau maior de ortodoxia e submissão do sistema financeiro do país a um modo de regulação alternativo, com um regime cambial mais flexível e liberalização de capitais. Em linhas gerais, este discurso pró-liberalização financeira assenta-se no apontamento de benefícios para o setor privado, que possuiria acesso inadequado ao crédito bancário sob o sistema vigente. Por fim, em tal contexto essa saída viria sendo crescentemente proposta enquanto uma estratégia geopolítica útil para fortalecer o poderio monetário chinês, através da diminuição da dependência das exportações e também do dólar enquanto moeda de reserva, sem contar o possível equacionamento de diversos desequilíbrios de tal regime de acumulação. 
O propósito principal desta parte do artigo não foi exatamente aprofundar os motivos que conduziram o Estado chinês a implementar regulamentações e medidas mais restritivas sobre a conta de capitais (em algumas dimensões dos investimentos e sobre o capital transnacional estrangeiro), mas sim trazer à tona seus resultados, problematizando alternativas colocadas diante do cenário macroeconômico futuro. O persistente controle governamental da China sobre os altos comandos de sua economia política doméstica, concomitantemente à recusa em aquiescer-se diante de uma agenda ortodoxa demandada principalmente pelas instituições multilaterais, se faz imprescindível para o entendimento da posição ocupada por tal país no sistema global. Portanto, a próxima seção buscará estabelecer de forma mais direta esta interface entre os controles do poder público e a economia em um cenário de desaceleração redesenhado pela crise financeira estadunidense de 2008, refletindo também sobre os encaminhamentos conferidos por ações recentes do Politburo do PCC.

\section{O "Novo Normal": transformações sistêmicas em meio à desaceleração pós-crise}

Aqui nesta seção será tratada, por fim, a desaceleração chinesa e suas implicações estruturais para a estratégia de desenvolvimento nacional, em interface também com o redesenho do modelo de crescimento pensado pelos policymakers. De início, serão destrinchados dois fatores de grande contribuição para esse arrefecimento, a saber: os limites e constrangimentos inexoráveis do próprio modelo desenvolvimentista, seguido no curso dos últimos trinta anos; e a crise financeira de 2008, impactando o epicentro da economia mundial e parceiros comerciais, cujos mercados são importantíssimos para o desempenho da China ${ }^{25}$. Tendo todo este mapeamento em vista, a etapa seguinte constituirá no estudo do paradigma do "Novo Normal" enquanto uma adequação ao novo cenário, requerendo um redesenho das políticas anteriormente vigentes e novas respostas à conjuntura por parte das autoridades (Hung, 2009; Yang e Huizenga, 2010).

A natureza contraditória do sino-capitalismo já foi assinalada por muitos autores nas mais diversas frentes, suscitando uma cacofonia de trajetórias possíveis, dependendo do enfoque dado aos diferentes desafios. Na visão do autor Ho-Fung Hung, por exemplo, a principal insustentabilidade do expansionismo econômico chinês diria respeito ao descompasso, crescente ao longo de praticamente todas as décadas de reformas, entre o sobre-investimento (em patamares bem mais severos do que os experimentados pelos Tigres Asiáticos) e o subconsumo (2009: p.190-1). Esse desnível teria alimentado restrições à diversificação nacional do regime produtivo. Outro ponto salientado é que a natureza descentralizada do crescimento da China a desviaria, em diversos sentidos, de um modelo mais efetivo e coordenado de Estado desenvolvimentista; com muitas unidades subnacionais atuando pró-ativamente 
para facilitar o crescimento de setores industriais selecionados, com esforços bem planejados e executados a nível das respectivas localidades (Saich, 2015). A totalidade desses esforços combinados, não obstante, acrescentaria um grau de competição muitas vezes deletério entre tais unidades, resultando na constituição desordenada e difusa de capacidade produtiva e infraestrutural.

O excesso de capacidade também se exacerbaria pela relativa falta de mobilidade geográfica e intersetorial das empresas domésticas, aumentando propensões de investimentos em setores e localidades muitas vezes já saturados. Ademais, governos provinciais e/ou municipais se utilizariam de barreiras protecionistas e desonerações a fim de competirem por inversões de capital com outras províncias ou cidades, em uma verdadeira fragmentação da economia nacional, bastante prejudicial a uma expansão mais virtuosa e que consolidasse eficientemente o capital doméstico (Hung, 2009: p.192). Somado a tudo isto, e conforme dito em várias oportunidades neste trabalho, o "baixo" desenvolvimento dos mercados financeiros obstaculizaria muitas empresas no sentido de diversificarem suas poupanças para investir em novos setores incipientes (onde poderiam lograr lucros mais altos), restringindo assim suas escolhas a investimentos em ativos fixos em seus próprios nichos.

O segundo problema do modelo de desenvolvimento seria o subconsumo. Tomando como exemplo os Tigres Asiáticos em seus estágios iniciais de aceleração industrial, vê-se como quase todos eles, praticamente, foram governados por regimes autoritários e disciplinados, em diferentes medidas, pela geopolítica da Guerra Fria, guardando ansiedades quanto a qualquer possibilidade de influências socialistas sobre as classes mais baixas. Esses Estados lograram tal objetivo (de neutralização dessas influências) mediante políticas distributivas preventivas como reforma agrária e provisão de educação gratuita, coexistindo paradoxalmente com a repressão ao trabalho organizado e organizações camponesas. Portanto, ao possibilitarem a transferência de frutos da expansão aos menos abastados, em especial à população rural, tais regimes revelaram-se economicamente inclusivos, ainda que politicamente excludentes. A redução das disparidades de renda e o crescente poder de compra dos desfavorecidos, por sua vez, também ajudou no fomento de consideráveis mercados domésticos em tais economias de industrialização tardia. A despeito de o sucesso de tais países ser oriundo principalmente do desempenho exportador (algo atestado pela colossal proporção das exportações sobre o PIB), o consumo doméstico exerceu rol indispensável no processo de decolagem, protegendo setores domésticos vulneráveis de flutuações no mercado mundial, em adição à provisão de demanda interna para setores nascentes antes de poderem competir propriamente no plano internacional (Hung, 2009: p.193-4).

Em contraste, o Partido-Estado chinês prosseguiu, no curso das reformas, com uma estratégia de crescimento bastante exitosa na atenuação da extrema pobreza ${ }^{26}$, mas sem igual sucesso no alívio da polarização social subsequente, agravada pelo que Hung alcunha de "draconiana supressão" governamental das vozes dissidentes na base 
da sociedade (2009: p.194). Desigualdades entre classes, regiões, e entre meio urbano e rural cresceram lado a lado com o período de milagre econômico e desenvolvimento rápido, fazendo com que a resiliência de inúmeras dificuldades, concomitantemente à distribuição assimétrica de renda, comprimisse bastante a expansão de um mercado consumidor de massas (Medeiros, 2010: p.15) ${ }^{27}$. A confluência desses fatores acumulação de sobre-investimentos e consumo deprimido - acentuou a dependência chinesa do mercado global no que tange ao imperativo de exportar seu excesso de capacidade, além de perpetrar externalidades negativas na forma de degradação ambiental. Simultaneamente, também pressionou a queda de preços de produtos finais em alguns setores industriais imprescindíveis, ocasionando declínio das margens de lucro de várias firmas (Hung, 2009: p.194-5).

Grande parcela dos receios sobre a "saúde" e os fundamentos do regime produtivo do país asiático foram arrefecidos, à priori, pela expansão robusta e solidez dos indicadores macroeconômicos latentes ao longo dos anos. Essas tendências de alta consolidaram o otimismo de investidores e agentes econômicos importantes com a China, tanto no cenário doméstico quanto internacional, impressionados principalmente com os resultados imediatos obtidos após o ingresso do país na OMC em 2001 e o ambiente envolvendo os Jogos Olímpicos de Beijing de 2008. Mas, como Hung pertinentemente denota, tal expansão e euforia, de forma irônica, acabaria apenas aprofundando os desequilíbrios do país, intensificando influxos de investimentos sem a necessária contrapartida de auxiliar o crescimento do consumo doméstico (2009: p.195). O acúmulo de reservas externas resultante de tal boom induziu à intensificação de uma nova expansão creditícia no setor bancário, abastecendo ainda mais investimentos financiados pela dívida, o que só realimentava tal ciclo vicioso. Não obstante o fato de os "milagres desenvolvimentistas do Leste Asiático" ficarem conhecidos exatamente pelas altas taxas de investimentos e baixas taxas de consumo, seus índices nem se comparam à magnitude de escala atingida pela China.

Com relação à crise americana do subprime, cumpre assinalar que a economia chinesa foi afetada por ela de forma muito distinta vis-à-vis outras potências. Pelo próprio fato de o país seguir uma estratégia de desenvolvimento com importante participação do comércio externo (embora não com a mesma densidade de outras nações como Hong Kong, Malásia ou Singapura), a crise não Ihe afetou tanto pelo canal das finanças, mas sim pelo lado real/produtivo da economia, especificamente nas indústrias processadoras de exportações (Schmidt, 2009). A resposta política do Estado chinês para equacionar tais problemáticas também foi diferente do resto das potências mundiais - a maior parte dos planos de resgate nos países desenvolvidos teve como prioridade estabilizar o sistema financeiro e gerar mais empregos. $\mathrm{Na}$ China, contudo, o pacote de estímulo objetivou, antes de tudo, a retomada do vigor exportador e o fomento à demanda doméstica (Medeiros, 2010: p.21; Yang e Huizenga, 2010: p.141; Hu, 2015: p.7-8). A despeito do repique no crescimento, o País do Meio 
permaneceu longe de ter logrado um nível de recuperação sustentável, tendo em vista todas as dificuldades ainda enfrentadas...

Em linhas gerais, houve queda instantânea e dramática tanto no comércio externo quanto nos fluxos de IED recebidos, bem como flutuações nos preços. As empresas de investimentos estrangeiros e as $\mathrm{SOE}$, a princípio, sentiram também seu efeito em uma proporção maior do que as firmas privadas domésticas, e o comércio processador (no setor manufatureiro) foi afetado de forma mais severa do que o comércio ordinário. Entretanto, o governo foi rápido para mitigar tais adversidades, mediante considerável pacote de estímulo ${ }^{28}$. A preocupação com os efeitos dessas turbulências sobre a atividade produtiva e o"pacto social" existente foi exatamente o que fez suas lideranças lançarem o programa, possibilitado pelo acúmulo de reservas externas ao longo dos anos e também pela alta arrecadação governamental (Yang e Huizenga, 2010: p.122). Em função de tais medidas, houve rápida retomada do crescimento (8,7\% em 2009), em uma cifra superior ao que era previsto para imensa maioria das economias do globo. A China, no entanto, também parecia dar reiterados sinais de extenuação de seu processo industrializante (além de movê-lo cada vez mais na fronteira tecnológica em múltiplos nichos), muito embora a urbanização continuasse em curso, representando uma possibilidade eventual de maiores instabilidades e desequilíbrios sociais ${ }^{29}$.

Mas foi afinal no volume de comércio exterior que a crise fez-se sentir mais forte, com as taxas de crescimento das exportações contraindo consideravelmente no espaço de poucos meses. Tal choque, a despeito de grave, não foi equanimemente distribuído entre os setores, regiões e tipos de empresas (Yang e Huizenga, 2010: p.130). Primeiramente, as exportações de produtos intensivos em trabalho foram menos prejudicadas do que as intensivas em capitais e tecnologias - bens chineses como têxteis, couro, calçados, entre outros apresentaram baixa elasticidade-renda da demanda, sendo menos sensíveis às alterações nas rendas em seus mercados de destino do que categorias mais elaboradas. Em segundo lugar, as empresas estrangeiras e estatais foram afetadas com maior gravidade do que as firmas privadas domésticas - quando a crise financeira se espalhou pelos demais países em uma recessão generalizada, muitas das empresas de investimentos externos retiraram projetos e atividades em função de dificuldades enfrentadas em suas matrizes e lugares de origem. Consequentemente, tanto as exportações quanto importações destas recuaram de forma abrupta. Já as SOE, maiores contribuintes das exportações intensivas em capital e tecnologia, foram mais afetadas pela recessão, onde consumidores tendem a substitui-las por produtos mais baratos e intensivos em trabalho, conforme dito.

Para revigorar as indústrias orientadas para exportações, jogadas em meio a um cenário imediato delicado, o governo também buscou agir pelo lado da demanda e fomentar o consumo, principalmente em mercados rurais ainda não explorados. Vale lembrar que, ao longo dos anos incipientes de crise (2008, 2009, 2010), as autoridades foram continuamente injetando um montante maior de gastos públicos conforme a 
necessidade de continuar incrementando a economia e fazendo-a acelerar novamente. Outra medida anti-cíclica de suma importância foi a intensificação dos abatimentos de impostos de valor agregado, originalmente introduzida em 1994 com objetivo de fomentar a exportação de manufaturados em novos mercados. Observa-se aqui, diante do aprofundamento dos excedentes comerciais por volta de 2005, que os policymakers nacionais até flexibilizaram um pouco tal política de incentivo; mas, em função do agravamento da crise, a mesma foi retomada em agosto de 2008. Mas, em termos das relações econômicas externas, nem todos os aspectos foram negativos para o país asiático: o declínio imediato do preço das commodities (como petróleo e derivados) em função da crise teve na China uma das grandes beneficiárias, ajudando a mitigar pressões inflacionárias (Schmidt, 2009: p.2). Somado a isto, a resposta internacional do país transparecia cada vez mais uma sintonia com sua imagem tradicionalmente cultivada de uma potência responsável, ao passo que evitava responsabilidades para além de suas capacidades enquanto maior país em desenvolvimento no mundo. Esta postura ficava clara, por exemplo, no compromisso firmado por Hu Jintao e Wen Jiabao no G20: a China atuaria como força estabilizadora no sistema financeiro internacional pela própria garantia de manutenção de seu crescimento (Schmidt, 2009; Hu, 2015).

Entretanto, pressupondo um cenário de aprofundamento maior da recessão e arrefecimento de demanda de forma prolongada, as lideranças chinesas serão provavelmente confrontadas com maiores clamores para acelerar os esforços visando reequilibrar o crescimento para além de políticas de fomento às exportações, sustentando a demanda e consumo domésticos (El-Erian, 2016). Isto viria acompanhado, no âmbito das relações externas, pelo aumento da crítica dos países ocidentais para que a China aumente substancialmente suas importações de modo a reduzir um pouco os próprios superávits comerciais, atenuando desequilíbrios engendrados na esfera global. Riscos existem nesta direção - como a mudança na postura de seus parceiros (principalmenteEUAeUniãoEuropeia), cada vezmais críticosquantoao que consideram e caracterizam como "comércio injusto". Em caso de prosseguir atuando mediante a depreciação do yuan (RMB) frente ao dólar (atitude já tomada pelo governo chinês em ocasiões anteriores, como julho de 2005 e agosto de 2008), de modo a fomentar sua indústria exportadora, tal linha poderia deslanchar medidas e ações protecionistas retaliatórias ${ }^{30}$. Essas dificuldades, somadas a outros conflitos em voga (imbróglios sobre violações de direitos de propriedade intelectual), poderiam dar margem a uma atmosfera mais hostil (ou adversa) com relação aos chineses, danificando prognósticos para as relações bilaterais. Nessa busca pelos objetivos domésticos, o país poderia acabar arriscando, inadvertidamente, amplificar a instabilidade financeira global, com os mercados no geral receando que tal desvalorização "roube" o crescimento de outras nações, incluindo aquelas dotadas de maiores dívidas externas e menos reservas para vislumbrarem financiamento (comparadas à própria China).

Como já foi observado, a mudança na estrutura econômica chinesa requereria, enquanto condição sine-qua-non para seu sucesso, um rebalanceamento do driver 
de crescimento do país na direção do consumo, com o setor terciário apresentando grandes oportunidades de empregabilidade urbana e geração de renda. Com o setor de serviços capaz de gerar mais empregos por unidade de produto do que o manufatureiro e de construção combinados, sua força relativa viria exercendo efeitos importantes na contenção do desemprego e prevenção de instabilidades sociais, considerações importantes para os policymakers. Exatamente por isto, mesmo com o PIB chinês desacelerando, a criação de postos de trabalho urbanos conseguiu atingir uma marca de 13 milhões em 2015, acima das metas e expectativas oficiais do governo (Roach, 2016). Também é preciso destacar também outro elemento favorável à China: suas massivas reservas externas, garantindo maiores condições de atravessar turbulências em meio a eventuais crises cambiais ou de liquidez. Evidentemente, tal "colchão" pode muito bem esvanecer em caso de prolongada fuga de capitais e perda de reservas estrangeiras disponíveis, algo bastante factível tendo em vista pontos como as incertezas nas expectativas dos agentes com suas condições econômicas, por exemplo. Após anos de acúmulo de reservas, as mesmas declinaram em 2015, refletindo adversidades neste percurso de estabilização do yuan e dos próprios mercados (conforme o gráfico 10) ${ }^{31}$.

Em certa medida, a desaceleração defrontada seria inevitável. O crescimento a dois dígitos ad infinitum seria impossível, em função das próprias dificuldades da China em continuar obtendo ganhos marginais na indústria. $\mathrm{O}$ crescimento de escala acabaria sendo tolhido em algum momento; sem contar que, caso perdurasse, a continuidade da absorção de recursos energéticos e insumos engendraria tensões ainda maiores sobre a questão ambiental (Hu, 2015). Conforme o próprio presidente Xi Jinping

Gráfico 10 - Reservas Internacionais da China (em bilhões de US\$), 2000-2015

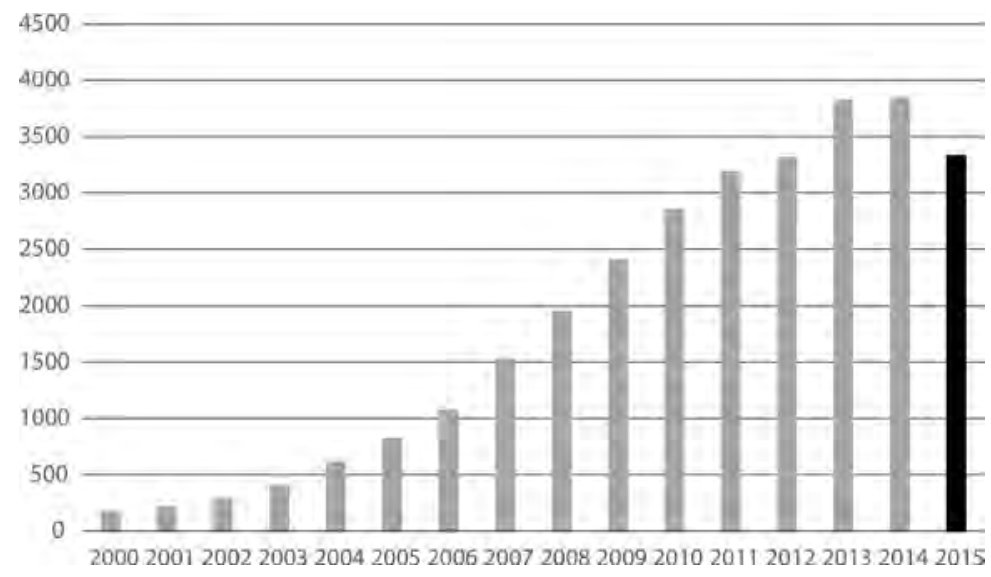

Fonte: National Bureau of Statistics, China Statistical Yearbook 2015; Trading Economics. 
havia salientado, o caminho chinês rumo ao "Novo Normal" faria referência a um reequilíbrio fundamental, englobando diversificação econômica ajustada a um ritmo mais sustentável de crescimento, distribuindo os ganhos de produtividade de forma mais equânime. Tal estágio também preveria melhorias, principalmente na dimensão qualitativa da vida chinesa, somada à maior integração do país no plano global.

Os próprios alvos setoriais elencados no $12^{\circ}$. Plano Quinquenal (2011-2015) ${ }^{32}$ foram um sinal claro, como pontua $\mathrm{Hu}$, do início de uma ênfase na qualidade e eficiência do modelo do desenvolvimento e não na quantidade (2015: p.4-5). Dentro do "Novo Normal", a concepção de desenvolvimento almejada giraria em torno de uma amálgama entre cinco pilares: inovação, coordenação, abertura, desenvolvimento verde e maior inclusão social. Evidentemente, as metas incrustradas em tal soft landing enfrentarão constrangimentos nada desprezíveis, principalmente relativos à criação de postos de emprego, mas o equacionamento de tais questões comporá parte do inevitável custo da transformação estrutural, preço a ser pago para o país ir adiante. A aguardada transição chinesa de um modelo ancorado nas exportações para outro pautado pelo consumo doméstico vem se mostrando muito mais instável e não linear do que se esperaria à primeira vista, principalmente no que tange aos picos e baixas no mercado acionário e a alta volatilidade do câmbio. Ainda assim, é imperativo enfatizar que o desempenho econômico da China se mantém notável (crescimento aproximado de 7\% em 2015), tornando-o, em certa medida, vítima das próprias altas expectativas que suscitou por tanto tempo (Stiglitz, 2015).

Contudo, conforme dito anteriormente no trabalho, se o governo conseguir galvanizar medidas efetivas pelo lado da demanda com políticas ativas voltadas ao mercado laboral, pelo menos a questão da empregabilidade poderá ser mais bem gerenciada - dando espaço para que políticas ótimas de reestruturação econômica sejam planejadas e postas em curso. Somado a isto, entretanto, há também um problema macro deflacionário: o excesso de capacidade sobre o qual a economia viria operando coloca pressões para baixo sobre os preços, com externalidades negativas para firmas endividadas, que passam a experimentar um aumento em sua alavancagem real (ajustada pela inflação). Uma abordagem preferível à consolidação via oferta seria, portanto, uma postura agressiva de expansionismo fiscal visando à demanda, podendo contrabalançar essas pressões comentadas. Entretanto, muitas vezes o debate relativo à política macroeconômica chinesa tem sido permeado por críticas ao esgotamento do pacote direcionado à crise de 2008. Como Stiglitz comenta, tais medidas, não obstante suas incompletudes, foram úteis em múltiplas vias dentro de um contexto emergencial (2015: p.2). Se, no entanto, as autoridades nacionais abraçarem medidas eficientes orientadas para a demanda, alargarão seu escopo até mesmo para reformas mais abrangentes pelo lado da oferta. Aqui está sendo deliberado o desempenho econômico e as perspectivas não só para a China mas para todo o mundo, tendo em vista a forte influência global da linha política adotada por Beijing (essa frase ficou um pouco obscura). 
Gráfico 11 - Composição do PIB por setor (\%), 1990-2014

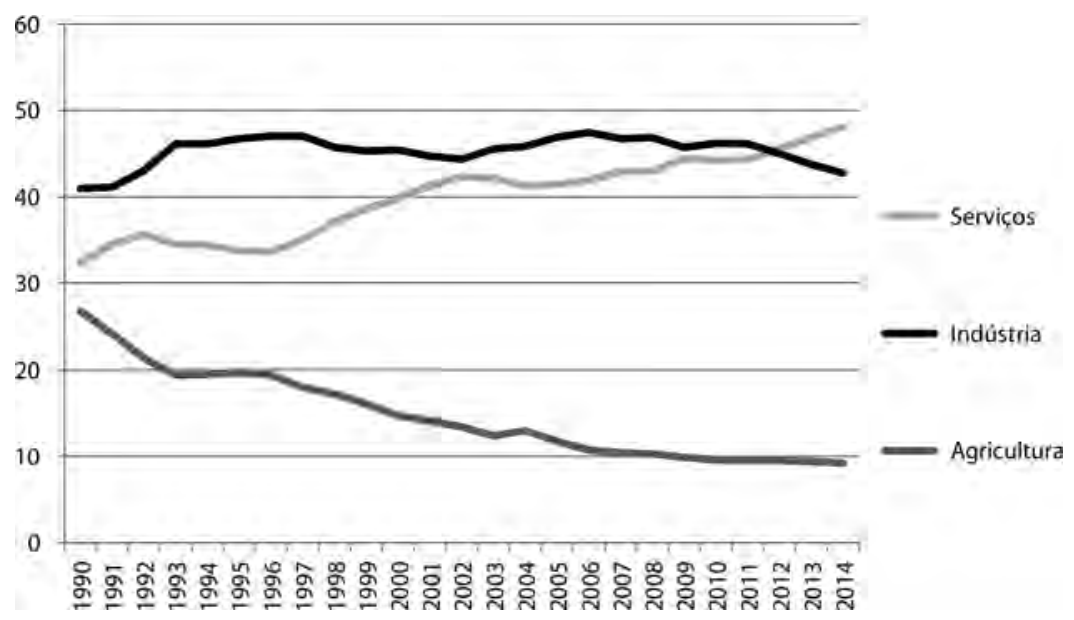

Fonte: Elaboração própria a partir de National Bureau of Statistics. China Statistical Yearbook 2015.

Já o $13^{\circ}$. Plano Quinquenal, mais recente, representa, de certa forma, um papel importantíssimo enquanto primeiro plano quinquenal chinês sob desaceleração e por conter mais claramente as mudanças pretendidas na orientação do modelo de desenvolvimento, perpassando o aprofundamento das reformas econômicas e uma maior clareza no arcabouço legal. Aqui se fez valer a grande influência de Xi Jinping e seus pontos cardeais imprescindíveis para a constituição de uma "sociedade próspera"33, a saber: a estabilização das taxas de crescimento de altas para médias; a melhoria nos padrões de vida; a proteção ambiental e o aprimoramento do sistema de governança nacional (Hong et al., 2015: p.6-7) ${ }^{34}$. O primeiro ponto implicaria em menores possibilidades de expansão para a indústria, com o setor de serviços passando a ganhar cada vez mais espaço (tendência já em curso, aliás, vide o gráfico 11) em uma economia com dificuldades de crescer muito acima de $6 \%$ ao ano. $O$ segundo, em busca por geração de empregos concomitantemente à ampliação dos serviços públicos essenciais e políticas direcionadas à erradicação definitiva da extrema miséria. A questão do meio ambiente teria lugar através encorajamento da produção de baixo uso carbonífero e melhoria da eficiência energética na matriz produtiva. $\mathrm{O}$ arcabouço institucional de governança, por último, se daria com melhorias setoriais, maior eficácia do aparato legal, aumento da credibilidade do judiciário e transparência do governo, dentre outros elementos...

Tal plano quinquenal também coloca a inovação enquanto um dos elementos primordiais a pautar a economia. Em caso de o governo conseguir cristalizar esta ambiciosa estratégia, o progresso científico do país nos mais diversos segmentos será bastante sólido, sendo fator adicional para ajudar na transição de modelo. Ademais, 
inovações no ambiente de negócios e em áreas de tecnologias nutririam toda uma nova classe de empreendedores na nação asiática, reformulando práticas tradicionais nas quais as operações eram comumente conduzidas. Todos esses fatores intrínsecos gerariam um câmbio fundamental no arcabouço competitivo global. A adoção de políticas nessas direções aponta perspectivas mais favoráveis às oportunidades de investimento. Concomitantemente, serão redefinidos os marcos de expansionismo "espacial" do desenvolvimento chinês, com foco em determinadas cidades como "clusters" - tal efeito permitiria às cidades do País do Meio melhor alocarem e utilizarem seus recursos para se beneficiarem de competividade mútua. Uma melhor sinergia entre os pólos urbanos é, de tal modo, também esperado.

Comentando brevemente sobre as implicações da desaceleração chinesa para o conjunto da economia internacional, é mister denotar que, sob o Novo Normal, para além das externalidades negativas geradas para parte do globo, o país também conferiu margem de oportunidades para outras nações, cujos destinos passam a depender largamente da diversificação e adaptação estrutural de seus regimes produtivos. Neste sentido, os tradicionais exportadores de commodities (agrícolas ou minerais) representariam o elo mais sensível a tal impacto estrutural, conforme a derrocada relativa da indústria e do setor manufatureiro chinês, somada ao desaquecimento da construção civil e dos investimentos, cristaliza uma redução drástica por tais produtos no mercado internacional (Wei, 2016).

Países produtores de bens intermediários, por seu turno, já se defrontariam com problemáticas de outra natureza, completamente distinta. Tendo em vista a alta proporção de semimanufaturados (basicamente, componentes intermediários) vendidos para a China objetivando conversão em bens finais duráveis nas fragmentadas cadeias asiáticas, a desaceleração, para tal categoria de países, faria tombar as exportações, ocasionando uma problemática árdua de ser equacionada. Entretanto, tais apontamentos não correspondem, evidentemente, a trajetórias futuras já determinadas e consumadas - afinal, tudo dependerá também do grau de sucesso do País do Meio em lograr a transição com poucas turbulências econômicas e sociais, tarefa dificílima mesmo para um país de estrutura política tão rígida. $\mathrm{O}$ aumento sistemático da renda per capita e do consumo médio da população (urbana ou rural) chinesa, nesta via, será condição fundamental para evitar tais percalços e reequilibrar o país dentro do cenário de menor crescimento; isto, é claro, se for concretizado. Além disso, faria o mercado doméstico nacional continuar um dos mais promissores no futuro, conferindo a muitas firmas e serviços oportunidades de médio e longo prazo, conforme perspectivas que apontam para maior margem de gastos dos consumidores.

Um terceiro conjunto de nações que pode vir a se beneficiar compreende aquelas na condição de competidoras diretas com a China: essas economias podem eventualmente tirar vantagem e aumentar sua fatia de mercado global (market share) na medida em que haveria uma tendência de relativo recuo chinês em diversos setores e atividades cada vez mais onerosos. É válido denotar aqui, uma vez mais, como o 
país foi "vitimizado" pelo próprio sucesso: o apogeu chinês consolidou ao longo dos anos um aumento no valor de sua força de trabalho, crescentemente qualificada tecnicamente e melhor remunerada (crescendo mais de 100\% na última década), obrigando a potência asiática a repensar sua lógica e ordenamento produtivo. Tendo em vista tal custo, muitas de suas indústrias perderam competitividade nos anos recentes, jogando ainda mais os prognósticos de desenvolvimento futuro sob a responsabilidade de ganhos de produtividade e inovação, e não mais de mão de obra barata (Jaguaribe, 2011; Hong et al., 2015; Wei, 2016). Evidentemente, tais ganhos provenientes do novo modelo de crescimento não seriam automáticos, mas sim logrados de modo incremental em meio às instabilidades, sendo importante para os países em desenvolvimento conduzirem reformas para capturar tais oportunidades competitivas, focando em eixos como transportes, logística e capital humano, etc.

Destarte, o arrefecimento também não é sinônimo, absolutamente, de uma perda de poder relativo da potência asiática no xadrez geopolítico internacional. Pelas próprias dimensões colossais de sua economia, mesmo um crescimento atual na base de $6 \%$ contribuiria significativamente para o produto bruto mundial em um cenário onde ecos da crise financeira ainda são muito sentidos, com muitos países europeus e emergentes passando por graves dificuldades. Por fim, para as demais nações, a melhor forma de cooperar com uma China em transformação é abraçar mudanças domésticas de fomento da produtividade e manutenção do lastro com a economia global.

\section{Conclusão: o papel das finanças em um novo paradigma de desenvolvimento}

Sumarizando as conclusões sobre as transformações na estrutura econômica chinesa, vê-se como esta, de forma geral, passou por uma série de evoluções e transformações institucionais ao longo das últimas três décadas, saindo de um modelo intensivo em trabalho, produzindo bens de baixo valor agregado para outro na condição de maior exportador mundial de manufaturados e com crescente sofisticação dos bens comercializados. A expectativa é que tal regime produtivo continue a galgar posições cada vez mais proeminentes nas cadeias globais de valor, somando-se à remoção de barreiras administrativas ao progresso industrial e aproveitando a sinergia íntima existente entre seu planejamento estatal e a alocação de mercado (Hong et al., 2015: p.23). Ao longo da reflexão proposta neste artigo buscou-se ver de que modo o fim do paradigma de desenvolvimento que pautou a China nos últimos trinta anos, com forte ênfase nas elevadas taxas de investimento e no volume comercial, colocou novas perspectivas e dificuldades, tanto práticas quanto estratégicas, para sua quinta geração de líderes, com especial atenção para o lado financeiro.

Em uma ótica positiva ou otimista, a desaceleração econômica é apontada como fator que compeliria as autoridades nacionais do país asiático a perseguirem 
um modelo mais sustentável no que tange à inclusão social e equilíbrio ambiental, representando uma nova fronteira das reformas de mercado onde elementos como bem estar, inovação e geração de renda passariam a ocupar lugar de destaque (Jaguaribe, 2011: p.47-8; Aglietta e Guo, 2013: p.162). Apesar das dificuldades enfrentadas, é plenamente plausível que a China equacione tais questões no médiolongo prazo, levando em conta suas próprias capacidades estatais e instrumentos econômicos disponíveis, como seu colchão de reservas internacionais, disponibilidade de oferta de crédito para políticas de indução de demanda, capacidade de engendrar novos arranjos institucionais, etc. Ademais, conforme amplia sua liderança econômica, o País do Meio será inevitavelmente conclamado também a assumir maiores responsabilidades na governança global, podendo ressignificar e reformular a ordem financeira internacional. Neste sentido, adquire um horizonte de ampliação de seu próprio poder a estratégia de internacionalização do renmimbi, elemento que só poderá ser viabilizado com retirada de controles sobre movimentação de capitais e reformulação de seu regime de acumulação e sistema financeiro, dentro de patamares estáveis de crescimento econômico. Entretanto, de muitas formas, a concretização dessa nova fase de crescimento também dependerá bastante de variáveis do contexto mundial em geral e das políticas e reações adotadas por outros países.

Já dentro de uma leitura mais cética ou pessimista, as dificuldades de conciliação de perda de dinamismo econômico, somadas às fugas de capitais e perda de confiança dos agentes e investidores financeiros, poderão comprometer relativamente a estabilidade transicional do modelo de desenvolvimento, a despeito da resiliência da ordem política mantida pelo PCC. Em tal quadro, é possível aventar movimentos centralizadores por parte dos gestores chineses no sentido de evitar conflitos sociais e blindar setores domésticos das volatilidades existentes, donde encontramos ecos tanto das contradições inerentes às próprias instituições da economia política do país quanto de efeitos da globalização pós-crise de 2008, de natureza qualitativamente distinta. Ante uma maior centralização do poder decisório e econômico, um movimento de liberalização de capitais no país possivelmente se veria atrasado ou postergado, tendo em vista o foco por parte do governo em outras políticas de estabilização.

Concluindo, a trajetória futura da China dependerá intimamente de qual dos dois cenários prevalecerá, visto que ambos implicam redefinições diferentes nas relações entre o Estado chinês e o mercado financeiro, pendendo seja para uma maior intervenção visando proteger interesses domésticos e ativos estatais expostos ao arrefecimento econômico ou uma liberalização da conta de capitais para a busca de objetivos estratégicos no plano externo. Caberá ao presidente Xi Jinping e aos altos escalões burocráticos do PCC e do governo chinês manusearem tal trade-off de modo a poderem, efetivamente, atingir os objetivos do paradigma do "Novo Normal", adentrando em um novo período de maior inclusão social e fortalecimento do mercado interno, além de instituições e políticas macroeconômicas voltadas para problemáticas há tanto tempo persistentes no gigante asiático. 


\section{Notas}

1 Desde o início das reformas, tal processo já guardaria uma duração de pelo menos trinta anos, com sucessivas ondas mudancistas e adaptações para com as distintas circunstâncias que se colocavam a cada momento. A despeito de, mesmo hoje, tal processo não estar supostamente completo (em função de muitas instituições efetivamente necessárias para uma economia de mercado nos moldes liberais permanecerem "rudimentares"), por volta de metade da década de 1990 a China já havia vitoriosamente transitado de um modelo de economia de comando para um vinculado aos mercados mundiais (Naughton, 2007: p.85).

${ }^{2}$ Em toda a trajetória chinesa, o papel governamental de aprimoramento da capacitação tecnológica foi notável, conferindo às exportações maior conteúdo tecnológico doméstico, decorrentes de uma forte política de ISI (industrialização substitutiva de importações). Esta tendência seria endossada, dentre outras coisas, pelo aumento de exportações não processadas e pela desaceleração das importações desde 2004 (\% do PIB), contribuindo para o crescimento do saldo comercial naquele período. Em suma, a ISI em bens intermediários, concomitante à elevação da capacidade produtiva da indústria pesada, assentou parte importante do boom recente do país (Medeiros, 2010: p.9).

${ }^{3}$ Isto deflagra uma mudança fundamental para com o período maoísta, onde a chamada industrialização do "Big Push" era enfática quanto a segmentos pesados de bens de capital (Naughton, 2007).

${ }^{4}$ Tal Congresso consolidava o triunfo da abordagem reformista de Deng, mediante cristalização de três pontos pivotais: o endosso, por parte do Congresso Nacional do Povo (CNP), dele como arquiteto da construção do "socialismo com características chinesas", com participação maior das forças de mercado; a sanção do documento formulador de diretrizes gerais para o modelo econômico; e, finalmente, o recrudescimento do controle estrito do PCC, com fortalecimento das células partidárias em todos os níveis administrativos. Este último ponto deflagrava um contraste nítido entre uma visão mais liberal para assuntos econômicos e outra mais rígida em se tratando de assuntos políticos (Saich, 2015: p.55-6).

${ }^{5}$ Que passaria o poder para a terceira geração de líderes do Partido, capitaneada por Jiang Zemin e Zhu Rongyi.

${ }^{6}$ Corroborando o famoso slogan utilizado pelo governo chinês (gestão Jiang Zemin): "Agarrem as grandes; soltem as pequenas!" ("Grasp the large; release the small!").

${ }^{7}$ O esforço ambicioso de reforma das estatais criou um setor público muito mais lucrativo se concentrando em grandes empresas na produção-chave de bens e setores básicos de rendes (McNally, 2014: p.65).

${ }^{8}$ Contrastando com outros países ex-comunistas, que se fizeram valer de "terapias de choque", incorrendo em recrudescimentos inflacionários agudos. Outra diferença importante foi que, enquanto no Leste Europeu houve austeridade e empoderamento da firma privada perante a pública, na China se deu uma interação entre as duas esferas (EMVs de propriedade coletiva muitas vezes recebendo tecnologias e equipamentos das estatais, ao passo que estas investiam diretamente nas mesmas EMVs). (Naughton, 1995; Amsden et al., 1996).

${ }^{9}$ As quatro ZEE iniciais foram: Shantou, Shenzhen, Xiamen e Zhuhai; todas localizadas na costa.

${ }^{10}$ Um importante componente estratégico de liberalização comercial chinesa foi a decisão governamental de garantir vantagens competitivas para firmas engajadas em atividades exportadoras. Tais empresas passavam a gozar então de licença para importarem, sem deveres ou tributos, quaisquer matérias primas ou insumos intermediários necessários à confecção de bens finais para exportação (Edmonds et al., 2008: p.172-3)

${ }^{11}$ Todas essas políticas comerciais contribuíram para acelerar o declínio relativo das SOE e auxiliar as firmas privadas domésticas a ganharem mercados no exterior.

${ }^{12}$ Um indicador comumente utilizado por investidores e/ou economistas para alardear tal definição seria a dependência exportadora do país, medida na relação com o PIB. Tal estatística, entretanto, guardaria suas imprecisões, na medida em que são conceitos "incomparáveis": as exportações são definidas pelo volume total de negócios, ao passo que o produto interno bruto é visto em termos de valor adicionado/ agregado. Seria isto que explicaria, por exemplo, nações asiáticas como Malásia perfazerem mais de 100\% das exportações sobre o PIB (Anderson, 2007: p.2-3).

${ }^{13}$ Constituem essas as exportações mais intensivas em P\&D (Pesquisa e Desenvolvimento), como nos setores: aeroespacial, computadores, produtos farmacêuticos, instrumentos científicos, maquinário elétrico, etc.

${ }^{14}$ A financeirização pode ser pensada, em termos gerais, como um processo onde o Estado se ateria crescentemente a um arranjo de meios financeiros (ex: mercados de capitais) de modo a gerenciar seus ativos e fomentar investimentos estratégicos. Tais meios compreenderiam três componentes inter-relacionados: a introdução de valores acionistas pelo governo para gestão de ativos; a expansão das instituições financeiras não-bancárias (também para fins de gerenciamento); e, finalmente, a provisão de veículos de financiamento para essas aplicarem em ativos fixos conduzidos pelo Estado (Wang, 2014: p.604-5).

${ }^{15}$ Conforme Naughton, o desenvolvimento financeiro de um país é decomposto em "aprofundado" e "ampliado". Aprofundamento financeiro seria o aumento na taxa de ativos financeiros em proporção 
à renda nacional/PIB. Tal relação seria uma medida do grau no qual a poupança se transforma em investimentos pelo intermédio de instituições financeiras. Em suma: o aprofundamento financeiro indica como efetivamente inst.financeiras realizam sua função primária: mobilizar poupança em investimentos. Já a ampliação financeira refere-se à maior variedade de instituições e instrumentos disponíveis, ocorrendo quando os mercados de capitais se desenvolvem. A ampliação financeira, em síntese, explicita maior poder de escolha para poupadores e investidores, facultando ao sistema combinar diferentes usos com múltiplas fontes de fundos. "Together, financial deepening and broadening are integral to the growth of an economy" (2007: p.450). A diversidade de instrumentos faculta ao sistema responder rapidamente aos choques econômicos e mudanças conforme estes emergem.

${ }^{16} \mathrm{M} 2$ (moeda e quase-moeda) equivaleria à identidade de M1 (moeda em poder do publico mais depósitos em bancos comerciais) acrescida de depósitos à prazo e títulos do governo em poder do público.

${ }^{17}$ Crédito este direcionado majoritariamente conforme critérios de estrutura de propriedade da firma ou conexões políticas junto ao PCC. O fato de as SOE serem as maiores beneficiárias de tal sistema de repressão financeira permite sugerir que tal fração representante do capital chinês seria, ao menos em tese, uma forte defensora da manutenção do controle de capitais.

${ }^{18}$ Assim, o excesso de inversões bancárias às empresas estatais, mesmo deficitárias, contribuiu para afrouxar os constrangimentos orçamentários.

${ }^{19}$ Uma leitura interessante que detalha os efeitos "estabilizadores" da política econômica chinesa (com relação aos vizinhos do Sudeste e Sul da Ásia) na esteira de tal crise pode ser encontrada em Glosny (2001).

${ }^{20}$ Três são os tipos de ações existentes no mercado financeiro do País do Meio: Ações-A, tipo primário e mais comum, disponível apenas para os cidadãos chineses adquirirem em yuan; Ações-B, determinadas em moeda-corrente estrangeira; e Ações-H, destinadas aos investidores de Hong Kong e outros mercados externos à China.

${ }^{21}$ Esta esquemática de controle de capitais também teria sido útil por irrigar o setor empresarial estatal com recursos e mitigar efeitos de contágio durante cenários de crise financeira, conforme a próxima seção detalhará.

22 Uma delas seria a divisão rígida e imprecisa entre um "capitalismo de Estado" antagonizando um "capitalismo neoliberal de mercado".

${ }^{23}$ O que pode ser explicado pela função-chave exercida pelos ativos fixos (SOE em particular) na própria dinâmica de acumulação. Esmiuçando o perfil de investimentos na China (altíssimos em paralelo com os padrões convencionais), vê-se como boa parte dos mesmos se constitui enquanto atividades econômicas executadas pelo setor estatal (Vermeiren e Dierckx, 2012: p.1653-4).

${ }^{24}$ Apesar de estas, sem dúvida, também obterem muitos ganhos com o regime cambial neomercantilista (garantido pelo controle de capitais), se tornando parcialmente incorporadas no bloco hegemônico a favor de tal sistema. Em outras palavras, tais firmas são permitidas a atraírem capitais externos apenas para financiarem seus investimentos, e não para propósitos especulativos, por exemplo. Mas é importante atentar que isto não significa que tal arcabouço regulatório não seja incontestado pelos diferentes atores (Vermeiren e Dierckx, 2012: p.1656).

${ }^{25}$ Dada a alta concentração de suas exportações (com seus cinco maiores parceiros comerciais perfazendo $70 \%$ do volume total vendido), a economia chinesa enfrentaria sérios problemas enquanto EUA, União Europeia e Japão permanecerem em recessão e/ou com baixas taxas de crescimento.

${ }^{26}$ Uma excelente leitura sobre as desigualdades de renda e processos de mobilidade social na China pode ser encontrada em Nogueira (2011).

${ }^{27}$ Denotando que o diferencial entre as taxas de crescimento do consumo e dos investimentos se alargou ainda mais desde 1989.

${ }^{28}$ Para equacionar impactos negativos da crise financeira, particularmente sobre exportações, o governo anunciou em novembro de 2008 um pacote inicial no valor de 4 trilhões de RMB (586 bilhões de dólares) de estímulo fiscal para os dois anos conseguintes (aprox. 13,3\% do PIB nominal chinês em 2008). O pacote objetivava induzir a demanda agregada nas seguintes áreas: infraestrutura para transporte público; construir habitações; desenvolvimento rural; projetos ambientais; tecnologia e inovação; ampliação dos gastos com seguridade social e saúde. A maior parcela do pacote $(37,5 \%)$ foi alocada em transportes. Além disso, tão logo o governo central anunciou tal medida, os governos locais (provinciais) também implementaram seus próprios planos e estímulos em escala mais micro (Yang e Huizenga, 2010: p.134).

${ }^{29} \mathrm{Na}$ esteira deste processo urbanizador vieram também maiores investimentos na indústria pesada (segmentos de aço, ferro, alumínio, vidro e química), uma ampliação da ISI e uma dinâmica diversificadora de exportações, impactando a natureza do padrão de crescimento. Medeiros considera importante assinalar que tal expansão já viria sendo desde 1997, embora tenha sido ampliada nos anos recentes (principalmente após o ingresso na $\mathrm{OMC}$ ), com o mercado interno e sua enorme escala se tornando fonte de atração de investimento externo e potencialidade de consumo (2010: p.10-1) 


\begin{abstract}
${ }^{30}$ Vale lembrar, no entanto, que tais políticas de desvalorização cambial condizem perfeitamente com uma tendência mais comum dentre economias emergentes e avançadas em anos recentes. Na esteira da crise financeira global, muitas delas focaram em políticas monetárias altamente expansionistas, redução drástica das taxas de juros, "quantitative easing", etc, de modo a injetar ânimo nas atividades produtivas (El-Erian, 2016).

${ }^{31}$ No curso (ainda bastante inicial) dessa reestruturação, muitos fatores negativos se deram (e/ou estão se dando ainda) na agenda financeira - o estouro de uma bolha de capitais; uma política cambial extremamente oscilante e mal administrada; êxodo de capital financeiro; etc (Roach, 2016).

32 Relacionados aos tópicos: mercado de trabalho; reestruturação produtiva (objetivando fortalecimento do setor terciário como carro-chefe da economia); inovação científica; bem-estar social e conservação.

${ }^{33}$ Por "sociedade próspera" implica-se em um país desenvolvido, industrializado e moderno, dotado de patamares mais elevados de riqueza, qualidade de vida e ambiental. O termo foi alcunhado pela primeira vez por Deng Xiaoping em 1979 para descrever uma projeção de futuro almejada. Posteriormente, foi trazida de volta à tona pela gestão Xi.

${ }^{34}$ Para além das questões econômicas, o PQ também trazia tópicos mais abstratos/gerais como cultura e civilização, apregoando a moralidade pública mediante maior senso de coletivismo.
\end{abstract}

\title{
Referências
}

AGLIETTA, M.; GUO, B. China's Development: Capitalism and Empire. London: Routledge, 2013.

AMSDEN, A. et al. "China's Macroeconomy, Environment, and Alternative Transition Model". World Development, Vol.24, N.2, 1996. pp.273-286.

ANDERSON, J. “Is China Export-Led?". UBS Investment Research - Asian Focus, 2007. pp.1-12.

EDMONDS, C. et al. "China's rise as a trading power". IN.: MCNALLY, Christopher. China's Emergent Political Economy: Capitalism in the Dragon's Lair. London: Routledge, 2008. pp.169-189.

EL-ERIAN, M. “The Chinese Economy's Great Wall". Project Syndicate, 2016. Disponível em: < https://www.project-syndicate.org/commentary/chinese-growth-slowdown-global-economicturmoil-by-mohamed-a--el-erian-2016-01 > Acesso em 13 de fevereiro de 2016.

GAO, X. "State-owned enterprises in China: How big are they?". World Bank, 2010. Disponível em: $<$ http://blogs.worldbank.org/eastasiapacific/state-owned-enterprises-in-china-how-big-arethey >Acesso em 27 de janeiro de 2016.

GLOSNY, M. "Stabilizing the backyard: recent developments in China's policy towards Southeast Asia". IN: EISENMAN, J. et al (eds.) China and the Developing World:

Beijing's Strategy for the Twenty-First Century. London: East Gate Books, 2007. p.150-186.

HONG, W. et al. "China's 13th Five-Year Plan (2016-2020): Redefining China's development paradigm under the new normal". China's Policy Think Piece Series Issue No.2. Dezembro de 2015. pp.1-25.

HU, A. "Embracing China's New Normal: When the Economy Is Still on Track". Foreign Affairs, Vol.94, N.3, 2015.

HUNG, H. "A Caveat: Is the Rise of China Sustainable?". IN.: HUNG, Ho-Fung (ed.). China and the Transformation of Global Capitalism. Baltimore: The Johns Hopkins University Press, 2009. pp.188-202.

JAGUARIBE, A. "China: estratégias de modernização alternativa”. Desenvolvimento em Debate, v.2, n.2, 2011. pp.39-49.

MCNALLY, C. China's Emergent Political Economy: Capitalism in the Dragon's Lair. London: Routledge, 2008.

. "The evolution and contemporary manifestations of Sino-capitalism". IN:

BECKER, Uwe. The Brics and emerging economies in comparative perspective: political economy, liberalization and institutional change. London: Routledge, 2014. pp.53-78. 
MEDEIROS, C. "Economia e Política do Desenvolvimento Recente na China". Revista de Economia Política, vol.19, n.3 (75), julho-setembro, 1999. pp.93-112.

. "O Ciclo Recente de Desenvolvimento Chinês e seus Desafios". Observatório de

Economia Global, N.3, 2010. pp.1-23.

NATIONAL BUREAU OF STATISTICS. China Statistical Yearbook 2009. Disponível em: < http:// www.stats.gov.cn/tjsj/ndsj/2009/indexeh.htm >.

. China Statistical Yearbook 2012. Disponível em: < http://www.stats.gov.cn/tjsj/

ndsj/2012/indexeh.htm >.

. China Statistical Yearbook 2014. Disponível em: < http://www.stats.gov.cn/tjsj/

ndsj/2014/indexeh.htm >.

. China Statistical Yearbook 2015. Disponível em: < http://www.stats.gov.cn/tjsj/

ndsj/2015/indexeh.htm >.

NAUGHTON, B. Growing Out of the Plan: Chinese Economic Reform, 1978-1993. Cambridge

University Press, 1995.

. The Chinese Economy: Transitions and Growth. Cambridge: The MIT Press, 2007.

NOGUEIRA, I. Desenvolvimento Econômico, Distribuição de Renda e Pobreza na China

Contemporânea. Tese de Doutorado. IE-UFRJ, 2011.

ROACH, S. "False Alarm on China". Project Syndicate, 2016. Disponível em < https://www.projectsyndicate.org/commentary/china-crisis-false-alarm-by-stephen-s--roach-2016-01 >. Acesso em 9 de fevereiro de 2016.

RODRIK, D. The Globalization Paradox: Democracy and the Future of the World Economy. London: W. W. Norton, 2011.

SAICH, T. The Governance and Politics of China. 4.ed. London: Palgrave Macmillan, 2015.

SCHMIDT, D. "The Financial Crisis and Its Impact on China”. China Analysis 67, Janeiro de 2009. pp.1-4.

STIGLITZ, J. "China's bumpy new normal". Nikkei Asian Review, 2016. Disponível em: < http:// asia.nikkei.com/Viewpoints/Viewpoints/China-s-bumpy-new-normal?page $=1>$. Acesso em 28/01/2016.

THE PEOPLE'S BANK OF CHINA. Annual Report. Vários anos. Disponível em: < http://www.pbc. gov.cn/english/130739/index.html >. Acessado em 25 de janeiro de 2016.

TRADING ECONOMICS. Trading Economics Database. Disponível em: < http://www. tradingeconomics.com/ >. Acessado em 25 de janeiro de 2016.

VERMEIREN, M.; DIERCKX, S. "Challenging Global Neoliberalism? The global political economy of China's capital controls". Third World Quarterly. 33:9, 2012. pp.1647-1668.

WANG, Y. "The rise of the 'shareholding state': financialization of economic management in China". Socio-Economic Review. Vol 13, No.3, 2015. pp.603-625.

WEl, S. "China's Slowdown and Asia's Economy". Project Syndicate, 2016. Disponível em: < http:// www.project-syndicate.org/commentary/china-slowdown-asian-economy-by-shang-jinwei-2016-01 > Acessado em 24 de janeiro de 2016.

WORLD BANK. World Development Indicators. Disponível em: < http://data.worldbank.org/datacatalog/world-development-indicators >.

YANG, L.; HUIZENGA, C. "China's Economy in the Global Economic Crisis: Impact and Policy Responses". In.: UNCTAD. The Financial and Economic Crisis of 2008-2009 and Developing Countries. New York: United Nations, 2010. Disponível em: < http://unctad.org/en/Docs/ gdsmdp20101_en.pdf >.pp.119-148. 